\title{
An Overview of COVID-19 and Its Vaccines
}

\author{
Nahid Rehman ${ }^{a}$ and Anjana Pandey ${ }^{a, *}$ \\ ${ }^{a}$ Department of Biotechnology, Motilal Nehru National Institute \\ of Technology (MNNIT) Allahabad, Prayagraj, 211004 U.P India \\ *e-mail:anjanap@mnnit.ac.in \\ Received June 30, 2021; revised July 15, 2021; accepted August 4, 2021
}

\begin{abstract}
Coronavirus pandemic, is a continuing catastrophe (COVID-19) triggered by Severe Acute Respiratory Syndrome Coronavirus 2 (SARS-CoV-2). The virus passes into the target cells by attaching itself to a receptor i.e., Human Angiotensin-converting enzyme 2 (hACE2). It consists of Spike structures created from glycoproteins that promote the virus entry into the target cells of host. The RBD of the S1 subunit on Spike proteins binds to the hACE2 receptor, which is mostly found in the lungs, particularly type-2 pneumocytes, causing human ACE2 receptors to be downregulated. Apart from nausea, vomiting, and chest tightness, which are unusual symptoms of COVID-19, the most common causes of death and severity are respiratory failure $(69.5 \%)$, sepsis or multi-organ failure (28\%), cardiac failure (14.6\%), and renal failure (14.6\%). Viral antigen-based or viral nucleic acid-based real-time RT-PCR is recommended for the diagnosis of COVID-19 suspects. Vaccination is essential for antiviral treatment. The study was conducted on viruses based on live-attenuated or non-activated viruses, recombinant viral vectors, DNA, VLPs and soluble proteins. Vaccine from Pfizer and BioNTech was the first that showed promising data on effectiveness. $90 \%$ efficacy of the vaccine was reported. BNT-162b2 (Pfizer, BioNTech) \& mRNA-1273 (Moderna) are mRNA based; AZD-1222 Ad5-CoV (AstraZeneca; Oxford University); Ad26.COV2.S (Johnson \& Johnson) are viral vector based and other vaccines have been granted emergency use authorization by FDA. Since RNA viruses are able to mutate readily and quickly the mutation in the existing strain can be Variants of concern (VOCs) that might diminish vaccine effectiveness. The latest Delta variant (B.1.671.2) has rapidly spread in India is emerging in the United States in mid-2021. It turns out to be the chief which is $6-8$ fold more resistant to neutralization by sera from COVID-19 convalescent and mRNA vaccinated individuals.
\end{abstract}

Keywords: SARS-CoV-2, Human Angiotensin-converting enzyme 2, Vaccination, Variants of concern, Delta variant (B.1.671.2)

DOI: $10.1134 / \mathrm{S} 2079086421070069$

\section{INTRODUCTION}

The current pandemic of COVID-19 additionally called as the coronavirus pandemic, is a continuing catastrophe (COVID-19) triggered by Severe Acute Respiratory Syndrome Coronavirus 2 (SARS-CoV-2). It had been initially known in Gregorian calendar month 2019 in the urban hub of China. In January 2020, the Global Health Association proclaimed the event a Public Health Emergency of International Fear, and in March 2020, it was declared a pandemic. "Over 116 million cases have been confirmed, with over 2.58 million deaths due to COVID-19," according to databases as of March 6, 2021, making it the most virulent pandemic in history.

COVID-19 signs are extremely abstract, from none to critically unhealthy. The virus mainly spreads through the air when people get in touch. It exit from an associate infected person as they breathe, cough, sneeze, or speak and enters another person via their mouth, nose, or eyes. In addition, it can be contracted through contaminated surfaces. Persons remain infec- tious for up to 2 weeks and may unfold the virus even if symptoms aren't present.

The preventive measures recommended include social distancing, the public carry of face masks, ventilation and filters, the washing of hands, covering the mouth once innate reflexes or coughs, the disinfection of surfaces and the monitoring of exposed or symptomatic individuals and their self-isolation. Many areas are developing and distributing vaccine units.

Worldwide authorities reacted by introducing travel constraints, lockdowns, geographical point risk controls and closures of facilities. Moreover, several places have worked to increase the test capability of the infected person and to trace contacts.

The pandemic reactions have led to major social and economic disturbances in the world and to the greatest global recession. Its juncture to rectify or cancel events, widespread panic-shopping shortages, agricultural disturbance and food shortages and reducing pollutant and greenhouse gases emissions. Several schools and public areas were partially or 
totally closed. The social media and mass media have circulated falsified information. The pandemic raised problems regarding racial and geographical discrimination, equity in health and, consequently, the balance between imperatives on public health and individual rights.

\section{HISTORY}

December 2019 witnessed the emergence of a recent extremely morbific Coronavirus, known as SARS-CoV-2. The virus passes into the target cells by attaching itself to a receptor i.e., Human Angiotensinconverting enzyme 2 (hACE2). It consists of Spike structures created from glycoproteins that promote the virus entry into the target cells of host. As per the literary texts the antecedently SARS-CoV by a chief mutation in binding sites of receptor and membrane proteins had turned into SARS-CoV-2 virus, liable for utmost alarming pandemic of COVID-19. These alterations are likely to be responsible for the acute spread and robust pathogenic mechanism of the virus and it is believed to be originated from bats.

Throughout in-depth analysis conducted on Coronaviruses as reported by (Bonilla-Aldana et al., 2020; Skariyachan et al., 2019; Walls et al., 2020), "a complete of six coronaviruses were acknowledged to be a reason of respiratory disorder, i.e., $\mathrm{HCoV}-\mathrm{OC} 43$, HCoV-229E, HCoV-NL63, HCoV-HKU1, SARS-CoV (severe acute metastasis syndrome coronavirus), and MERS-CoV (middle east metastasis syndrome coronavirus)." Apparently, out of those mentioned above SARS-CoV and MERS-CoV were reported as more morbific. Their origin was reported from the province, China in the year 2002 and Arabian Peninsula in 2012 severally.

The SARS-CoV-2 occurrence was detected once a big intake of patients in the native hospitals of Wuhan in Gregorian calendar month 2019. They were experiencing common medical symptoms of respiratory disease. Early February 2020, United Nations agency confirmed the novel Coronavirus baptized as SARSCoV-2 was liable for these indications, and additionally acknowledged this pathological ailment as COVID-19. The unsatisfactory occurrence of the COVID-19 (Coronavirus sickness 2019) state of affairs unfold throughout the globe was proclaimed as a pandemic disease by World Health Organization.

\section{EPIDEMIOLOGY}

In early December 2019, a number of local health workers in Wuhan, Hubei Province, Mainland China, were diagnosed with pneumonia-like 69 symptoms of an unknown source, which were epidemiologically linked to the seafood market (Zhu et al., 2020). WHO provisionally named the infection 2019-novel Coronavirus (2019-nCoV) on January 7, 2020 (Huang et al., 2020), and on February 11, 2020, the Coronavi- rus Study Group (CSG) of the International Committee on Taxonomy of Viruses (ICTV) renamed it SARS-CoV-2 (Gorbalenya et al., 2020), and the disease caused by SARS-CoV-2 was dubbed COVID-19 (Chen et al., 2020). The WHO designated the 2019$\mathrm{nCoV}$ epidemic as a Public Health Emergency of International Concern (PHEIC) on January 30, 2020, the sixth and most recent in the chronological order after

(i) H1N1 in 2009,

(ii) Polio in 2014,

(iii) Ebola in 2014 in West Africa,

(iv) Zika in 2016, and,

(v) Ebola in the Democratic Republic of Congo in formatting is required in a way that 2019 falls below the ebola.

The World Health Organization declared COVID-19 a pandemic on March 11, 2020 (Li et al., 2020). As of November 30, 2020, this developing highly contagious disease had infected 62,195,274 people worldwide, resulting in 1,453,355 deaths and a fatality rate of 2.34 percent (WHO COVID-19 Global Situation Report, 2020).

Virology is a separate topic and should be presented in a separate heading in capital letters and bold style. It should not be included in epidemiology. Coronaviruses are peplomers exhibit crown shape, positivesense ssRNA (single strand RNA) virus, in the pleomorphic form with $80-160 \mathrm{~nm}$ size (Shang et al., 2020). It's a non-segmented RNA virus with a size range of 26 to $32 \mathrm{~kb}$. They are classified as nidoviruses, with the family coronaviridae and the subfamily coronavineae, which is further divided into $\alpha, \beta, \Upsilon$, and $\delta$ genus. The human population is mostly affected by the $\alpha$, and $\beta$, genera of Coronaviruses. $\mathrm{HCoV}-229 \mathrm{E}$ (Human Coronavirus) and NL63 are members of the $\alpha$ genus, while $\beta$ includes HKU1, 229E, OC43, MERS-CoV, SARS-CoV, and the most recent outbreak, SARS-CoV-2.

Single-strand RNA, nucleocapsid protein, envelop protein, membrane protein, and spike glycoprotein (S) have all been found in Coronavirus (Lei et al., 2018). The spike (S) glycoprotein is responsible for the Coronavirus's unique characteristic, which is a crown-like structure on the virus's outer surface. $\mathrm{S}$-protein is divided into two subunits, $\mathrm{S} 1$ and $\mathrm{S} 2$. The $\mathrm{S} 1$ subunit is further divided into three domains, with A, B, and C (Angeletti et al., 2020). Domain A of the CoVOC43 and CoV-HKU1 subunit S1 interacts to the host receptors in general (Hulswit et al., 2019). MERS$\mathrm{CoV}$, on the other hand, has been shown to use both A and B domains to enter cells via the DPP4 (Dipeptidyl peptidase-4) receptor (Park et al., 2019). The $\mathrm{B}$ domain of SARS-CoV-2 and SARS-CoV is claimed to engage directly with the human angiotensin-converting enzyme-2 (hACE) receptor, allowing the virus to enter the target cell (Cui et al., 2019). Fascinatingly, the $\mathrm{S}$ protein structure in both SARS-CoV and new 


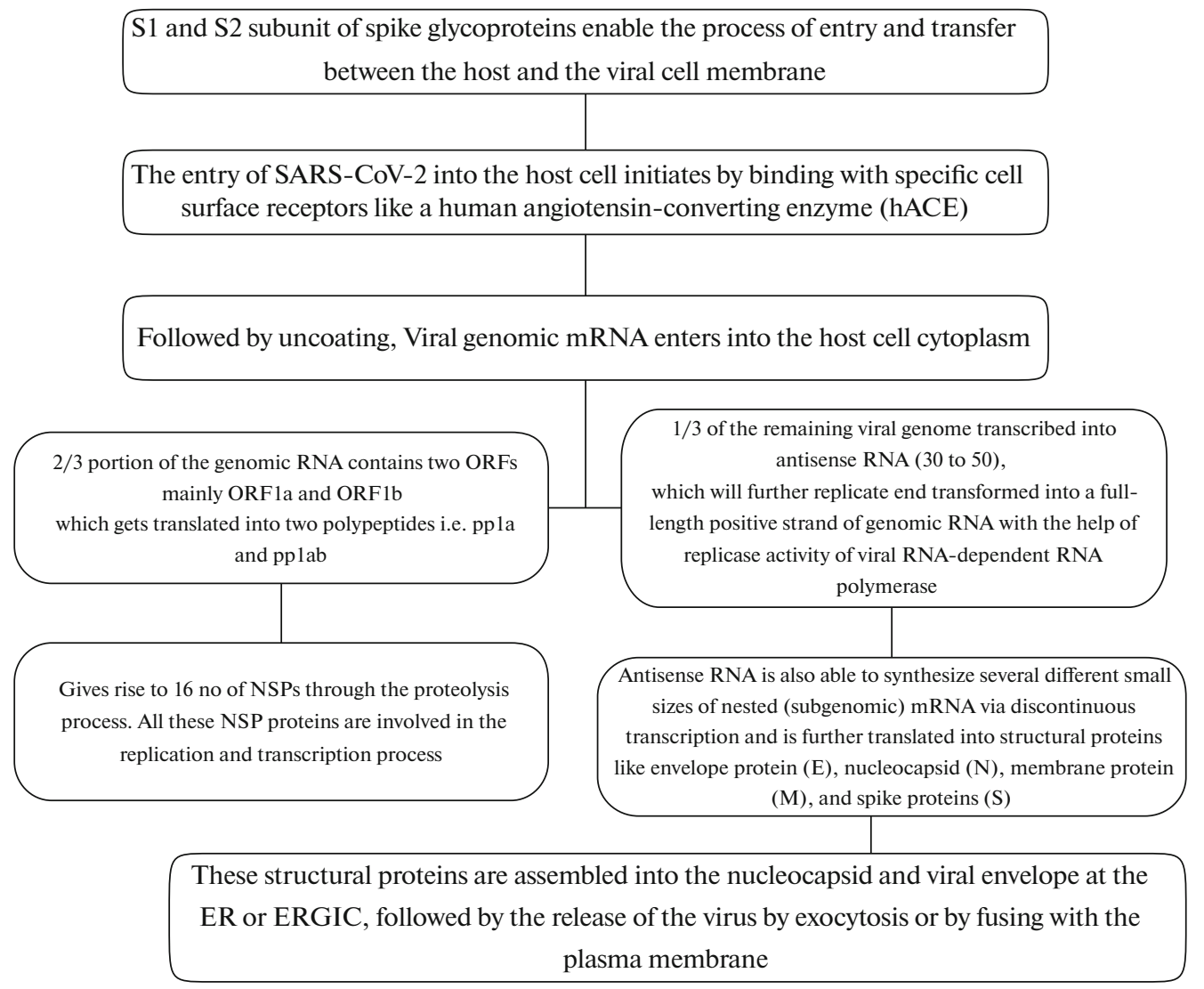

Fig. 1. Viral replication inside the host cell.

SARS-CoV-2 viruses is nearly identical, with only minor changes.

\section{GENOME STRUCTURE OF SARS-COV, MERS-CoV, AND SARS-CoV-2}

SARS-CoV, MERS-CoV, and SARS-CoV-2 are human CoVs that have a number of structural similarities and are root cause of severe pneumonia. CoVs have the following genetic organisation: ORFlab, 5 '-replicase (rep gene), spike (S), envelope (E), membrane (M), nucleocapsid (N)-3', with short untranslated regions at both ends. Du et al. (2009) mentioned that the rep gene is reported to encode for non-structural proteins (NSPs) and takes up around two-thirds of the viral genome. The genome of $\mathrm{CoV}$ has been shown to have a variety of open reading frames (ORFs). Approximately two-thirds of viral RNA is encoded by the first ORFs (ORF1a/b), which translate into two polyproteins, ppla and pplab, which encode 16 NSPs. Spike (S), envelope (E), membrane $(\mathrm{M})$, and nucleocapsid (N) proteins, as well as other accessory proteins, are involved in the host's innate immune system's response (Cui et al., 2019). The $\mathrm{S}$ protein (transmembrane glycoprotein) has two subunits, S1 and $138 \mathrm{~S} 2$, which are required for viral receptor engagement and subsequent entry. In SARS-
$\mathrm{CoV}$ and SARS-CoV-2, the S1 subunit with the receptor-binding domain (RBD) interacts with the ACE-2 receptor on host cells, but in MERS-CoV, it interacts with the DPP4 receptor on host cells. The S2 component is responsible for the fusion of viral and host cell membranes (Du et al., 2009; Xia et al., 2014). Because it is involved in receptor identification, virus attachment, and entrance into the host cell, the spike (S) protein of SARS-CoV is the most essential target for the development of SARS-CoV vaccines and treatments (Due et al., 2009). The E protein is required for virus intracellular transit and assembly, the M protein is involved in viral assembly and morphogenesis, and the $\mathrm{N}$ protein is required for RNA synthesis (Song et al., 2019). The Wuhan-Hu-1 Coronavirus (WHCV) genome was identified from a COVID-19-infected pneumonia patient, a worker at a Wuhan seafood market. SARS-CoV-2 has a genome length of $29.9 \mathrm{~kb}(\mathrm{Wu}$ et al., 2020), while MERS-CoV and SARS-CoV have genome lengths of 30.1 and $27.9 \mathrm{~kb}$, respectively (de Wit et al., 2016). Although the genomic sequence of SARS-CoV-2 is comparable to that of SARS-CoV and MERS-CoV, the genome makeup of SARS-CoV-2 is markedly different from that of SARS-CoV and MERS-CoV (Prompetchara et al., 2020). After the viral genome was sequenced, phylogenetic results were obtained, and evolutionary patterns were investigated, 
it was determined that the bat was the primary host of the virus, and that SARS-CoV-2 was transferred from bats to people via pangolins as an intermediary host. The genomic sequence of SARS-CoV-2 is 96.2 percent identical to Bat-CoV-RaTG13, 79.5 percent similar to SARS-CoV, and roughly 50 percent similar to MERS-CoV (Guo et al., 2020). Scientists discovered that SARS-CoV-2 had higher sequence homology to Bat-CoV-RaTG13, which was previously found in Rhinolophusaffinis (commonly known as 'HorseShoebat') from Yunnan Province, than Bat-SLCoVZC45 and Bat-SL-CoVZC21, identical sequence derived from $>1000$ pangolin metagenomic samples (SCA, 2020) states that the origin of SARS-CoV-2 is Chinese chrysanthemum bat. Because the SARSCoV-2 isolated from pangolins had roughly 85.5 percent to 92.4 percent similarity between the genomes of CoVs, pangolins were identified as intermediate hosts (Lam et al., 2020). Camels have also been identified as intermediate hosts for MERS, with MERS-CoV isolates from camels and humans showing 99 percent identity (Cui et al., 2019).

\section{ENTRY AND REPLICATION OF CORONAVIRUS IN A HOST CELL}

In the case of SARS-CoV and SARS-CoV-2, the Coronavirus penetrates the host cell by attaching to certain cell surface receptors such as hACE-2 and CD90L (L-sign), however in the case of MERS-CoV, the DPP4 receptor is used ( $\mathrm{Li}$ et al., 2020). The RBD of the S1 monetary unit binds to the hACE2 receptor in the case of SARS-CoV-2, whereas the S2 monetary unit facilitates fusion between the host and therefore the microorganism plasma membrane ( $\mathrm{Li}$ et al., 2005). On the S1 and S2 subunits of SARS-CoV-2, there are four unique amino acids that end up within furin cleavage sites (Cui et al., 2019). The cleavage of ' $S$ ' occurs at the sureary gift between S1 and S2 subunits, which is a non-covalent gift at intervals the membrane's boundary. When the peptidase enzyme binds to the hACE receptor, it normally lyses the supermolecule gift between the S1 and S2 subunits (Liu et al., 2015). This lysis causes irreversible valency conformation alterations, which increases the supermolecule's binding affinity and, as a result, substantially activates the supermolecule for fusion (Belouzard et al., 2009). The S1 monetary unit's modified receptor binding sites and furin cleavage sites could possibly be contributing to the virus's rapid transmission, reproduction, and infectivity (Zhou et al., 2020). After binding and fusion of the ' $\mathrm{S}$ ' supermolecule, a microorganism genomic messenger RNA reaches the host cell protoplasm through receptor-mediated endocytosis or directly through the host plasma membrane. In general, the Coronavirus genomic RNA is extremely lengthy, with approximately thirty thousand nucleotides. Furthermore, genomic RNA contains a 6-10 open reading frame (ORF) that specifies the replicase factor (Cowling and Leung, 2020). ORF1a (Open Reading Frame) and ORF1b both give a couple of two-thirds of genomic RNA, which they then convert into two huge polyproteins, ppla and pplab, respectively. Furthermore, two proteolytic enzymes, namely enzyme-like proteolytic enzyme (PLpro) and 3C like proteolytic enzyme (3CLpro), break these polyproteins into non-structural proteins (NSP) (Schoeman and Fielding, 2019). The polyproteins pplab and pplb, respectively, are NSP1-11 and NSP1-16. These proteins are also known as replicase and polymerase proteins because they are involved in the replication and transcription processes. These NSPs currently establish themselves at intervals along the rough endoplasmic reticulum (RER) membrane and form the replicase-transcription complex (RTC). These NSPs have specific functions such as NSP1 (cellular messenger RNA degradation and antiviral signalling inhibition), NSP12 (RNA dependent RNA enzyme activity), NSP13 (helicase activity), and NSP14 (exoribonuclease activity), among others (endoribonuclease activity). With the help of an RNAdependent RNA enzyme, a simple fraction of the microorganism order that is coded for remaining ORF transcribed into antisense RNA (thirty to fifty) (Fehr and Perlman, 2015). With the help of the replicase activity of microorganism RNA-dependent RNA enzyme, this antisense RNA is increasingly reproduced and converted to a full-length positive strand of genomic RNA (Cui et al., 2019).

\section{PATHOGENESIS}

Despite the fact that the pathogenesis of COVID19 is unknown, the pathogenesis of MERS-CoV and SARS-CoV remains the finest source of information on COVID-19 (Li et al., 2020). Research has shown that changed residues of the S1 subunit's RBD (receptor binding domain), the presence of RRAR, and a partially opened form of the ' $\mathrm{S}$ ' trimer could be a reason for COVID-19's high pathogenicity and transmission capabilities. The RBD of the S1 subunit on Spike proteins binds to the hACE2 receptor, which is mostly found in the lungs, particularly type-2 pneumocytes, causing human ACE2 receptors to be downregulated (Kuba et al., 2005; Xu et al., 2020). Increased angiotensin-2 (AT2) synthesis by the related enzyme ACE1 may result from downregulation of ACE2 receptors. Increased pulmonary vascular permeability due to an increase in AT2 production may induce lung damage (Imai et al., 2005). Furthermore, SARS-CoV-2 contains antigen-presenting cells that attach to a host's dendritic cell, activating macrophages and causing a severe immunological reaction, resulting in the excessive release of pro-inflammatory cytokines (IFN, IL-1, IFN-, IL-6, IL-12, IL-18, IL-33, TNF, TGF, and others) and chemokines (CCL2, CCL3, CCL5, CXCL8, CXCL9, CXCL10) (Cameron et al., 2008). These inflammatory mediators induce more damage 


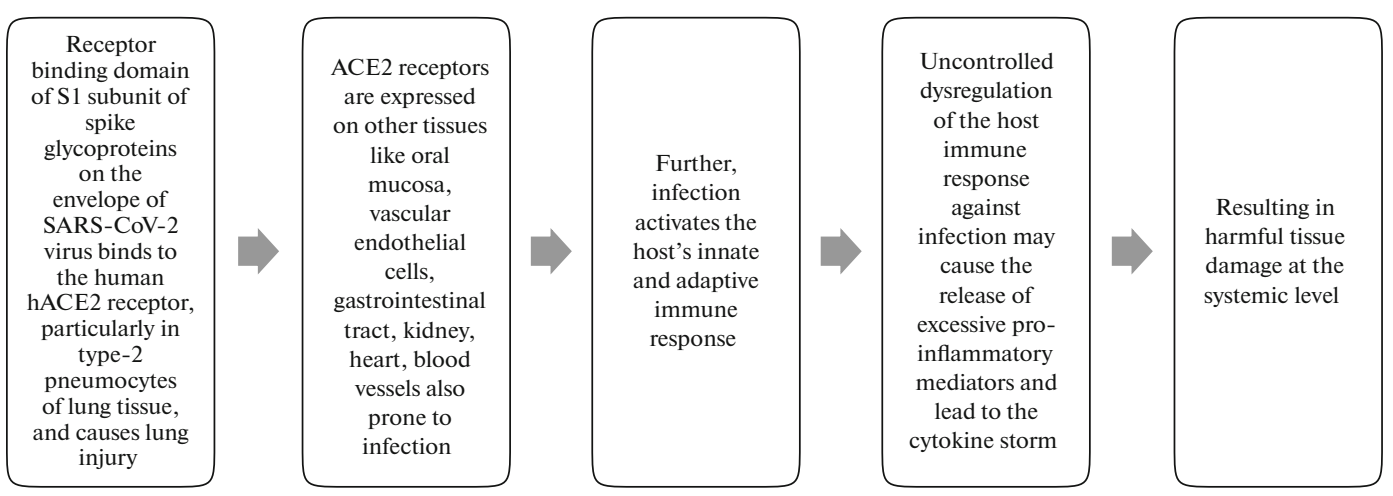

Fig. 2. Schematic representation of pathogenesis and clinical manifestation of COVID-19.

to the epithelial cells lining and travel via the bloodstream, causing harm to other organs ( $\mathrm{Li}$ et al., 2020b; Rothan and Byrareddy, 2020).

\section{CLINICAL SYMPTOMS}

The acute manifestations of COVID-19 infection can appear after 5-6 days of incubation, depending on the person's age and immune status. People above the age of 60 are more susceptible to SARS-CoV-2 ( $\mathrm{Li}$ et al., 2020). Fever (more than $80 \%$ of cases), cough (more than $60 \%$ of cases), exhaustion (more than $35 \%$ of cases), production of sputum (more than $30 \%$ of cases), and shortness of breath (more than 15 percent cases) are the most prevalent clinical symptoms of SARS-CoV-2 infection. Headache, muscle weakness, dyspnea, sore throat, and pleuritic pain (10-15 percent) are fewer common symptoms. Apart from nausea, vomiting, and chest tightness, which are unusual symptoms of COVID-19, the most common causes of death and severity are respiratory failure $(69.5 \%)$, sepsis or multi-organ failure $(28 \%)$, cardiac failure $(14.6 \%)$, and renal failure (14.6\%) (Heymann and Shindo, 2020; Zhang et al., 2020). Guan et al. (2003) published "a report on clinical characteristics of COVID-19 in China in the New England Journal of Medicine recently where a total of 1099 patients with COVID-19 instances were studied. Fever (88.7\%), cough $(67.8 \%)$, and CT scan abnormalities (86.2 percent) were the most prevalent symptoms, according to the report. Ground-glass opacity and patchy bilateral shadowing were the most prevalent patterns seen on CT images. The occurrence of lymphocytopenia $(83.2 \%)$, thrombocytopenia $(36.2 \%)$, and leukopenia (33.7 percent) was also discovered in the laboratory study.

\section{DIAGNOSIS}

The diagnosis of COVID-19 can be done in a variety of ways. Once confirmed, people must be isolated from the rest of the community. As a result, the scope of preliminary prevention is restricted to diagnostics.
Antigen-based or nucleic acid-based laboratory tests, such as fast testing and real-time RT-PCR tests, are used to determine the presence of SARS-CoV. For sero surveillance studies to assess the prevalence of infection in the community, blood/serum is used to identify $\operatorname{IgM}$ (current/recent infection) or IgG (past infection). To detect current COVID-19 infection, a throat swab or nasopharyngeal swab is obtained from suspected cases for viral nucleic acid-based detection assays.

Viral antigen-based or viral nucleic acid-based real-time RT-PCR is recommended for the diagnosis of COVID-19 suspects as well as contacts of COVID-19 positives, whereas Antibody-based rapid detection tests are recommended primarily for surveillance, so that appropriate treatment and management procedures can be followed after laboratory confirmation to avert further spread. After a minimum of 7 days from the onset of symptoms, the fast antibody detection will be useful. Rapid tests are useful for epidemiological research and surveillance. All of the above tests must be performed under physician supervision.

\section{PROPOSED TREATMENT}

\section{Symptomatic Therapy (Need-Based Therapy)}

This treatment is based on symptomatic and oxygen therapy, which is the primary treatment intervention for patients with severe infections. In cases of

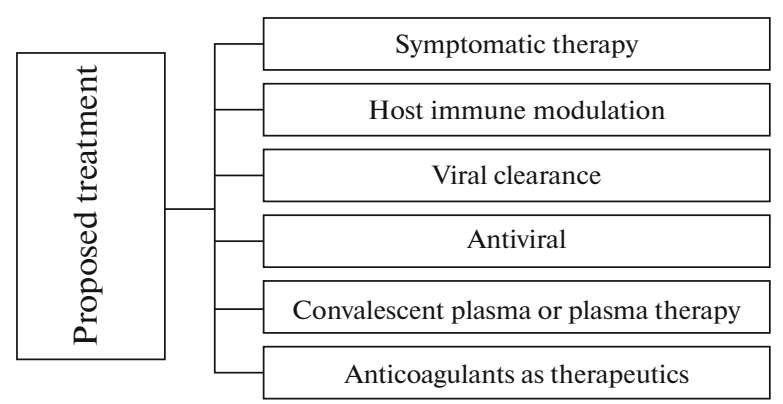

Fig. 3. Treatment strategies for COVID-19 infection. 
Table 1. A preliminary thermal will be used to confirm the suspected cases. COVID-19 surveillance tools include those developed in laboratories

\begin{tabular}{|c|c|c|}
\hline 1 & $\begin{array}{l}\text { Thermal scanning } \\
\text { and Infrared sensors }\end{array}$ & $\begin{array}{l}\text { It's a secure technique to keep the people who are afflicted separate from the rest of the popu- } \\
\text { lation. Infrared radiation is detected and captured as heat by thermal cameras, which then } \\
\text { converts it to a visual image. The use of such cameras at a variety of public places, including as } \\
\text { airports, train stations, academic institutions, and research centres, is advantageous for screen- } \\
\text { ing the body temperature of big crowds with an accuracy of up to } 0.5^{\circ} \mathrm{C} \text {. Thermal cameras } \\
\text { need a longer wavelength of IR energy to operate (Lee et al., 2020). Infrared scanners are used } \\
\text { to scan individuals, however screening a large crowd takes longer. As a result, it's possible to } \\
\text { conclude that thermal cameras are a superior alternative for large-scale screening than IR } \\
\text { scanners }\end{array}$ \\
\hline 2 & $\begin{array}{l}\text { Nucleic acid amplifi- } \\
\text { cation test (NAAT) }\end{array}$ & $\begin{array}{l}\text { To confirm COVID-19 disease NAAT is being utilized by employing a real-time fluorescence } \\
\text { polymerase chain reaction (RT-PCR) on a nasal swab or blood sample, as per the WHO pro- } \\
\text { tocol (Wu et al., 2020). "If a viral load is very low, a limited sensitivity is observed due to the } \\
\text { low detection of virus nucleic acid," according to recent literature. This low detection rate may } \\
\text { result in false-negative results" (Dai et al., 2020). The US Food and Drug Administration } \\
\text { (FDA) and other regulatory agencies have granted emergency use authorization for diagnostic } \\
\text { kits that use RT-PCR technology to identify COVID-19 (Devices, 2020). RT-PCR, on the } \\
\text { other hand, has a number of possible pre-analytical and analytical hazards. False identifica- } \\
\text { tion, sample preparation, specificity, sensitivity, and stability concerns are all dangers, and the } \\
\text { process is time-consuming. Although equipment calibration is a major worry since it can lead } \\
\text { to misleading results, it is highly advised that the RT-PCR must be calibrated on a frequent } \\
\text { basis to avoid any false readings }\end{array}$ \\
\hline 3 & $\begin{array}{l}\text { Computerized } \\
\text { tomography scan }\end{array}$ & $\begin{array}{l}\text { Investigators strongly recommend Chest CT imagery to have a high rate of viral pneumonia } \\
\text { detection. Other findings, such as ground glass opacities (GGOs) with patchy consolidation } \\
\text { and a preference for subsequent or lower lobe participation for COVID-19 (Zu et al., 2020). Li } \\
\text { et al. ( } 2020 \text { ) have reported on the evolution and clinical implementation of a combined SARS- } \\
\text { CoV-2 diagnostic antibody test for rapid IgM-IgG. A quick (within } 15 \text { minutes) and simple } \\
\text { lateral flow immunosurge has been developed by this group. Simultaneously, IgM and IgG } \\
\text { can be detected against the SARS-CoV-2 virus at several stages of the COVD-19 in this devel- } \\
\text { oped immunoassay }\end{array}$ \\
\hline
\end{tabular}

respiratory failure that is resistant to oxygen therapy, mechanical ventilation may be required, whereas hemodynamic support is required to manage septic shock. WHO published a document on the 28th of January 2020 that summarized WHO standards and scientific information gathered from the handling of previous epidemics caused by Human CoVs. Strategies for treating respiratory failure, such as protective mechanical ventilation and high-flow nasal oxygen (HFNO) or non-invasive 436 ventilation (NIV), were mentioned among the recommendations (Cascella et al., 2020). After a case-by-case study, extracorporeal membrane oxygenation (ECMO) for patients with refractory hypoxemia despite lung-protective ventilation should be considered. Those who have had poor results may benefit from prone position ventilation (Cascella et al., 2020).

\section{Host Immune Modulation}

Individuals who are exposed to SARS-CoV-2 for the first time have a good initial host defense in the lungs, which is associated with modest symptoms and illness resolution. In some situations, viral immune evasion might result in refractory alveolar injury, poor lung repair mechanisms, and systemic inflammation with accompanying organ dysfunction (Hall et al., 2020). The quickest path to success in the investigation and treatment of individuals with critical disease owing to COVID-19 is an immunological phenotypedriven strategy to immunomodulation that may involve anti-cytokine therapy in carefully selected patients and immune stimulatory medicines in others (Hall et al., 2020).

\section{Viral Clearance}

The most effective approach to treat SARS, MERS, and COVID-19 is to see if currently available antiviral medications are effective. Many antiviral medicines, such as interferons (IFNs), darunavir/cobicistat (prezcobix), ribavirin, and lopinavirritonavir, were studied during previous-coronavirus epidemics, with a few showings promise in vitro results (Chu et al., 2004). Lopinavir, an antiretroviral medicine, inhibits the protease enzyme, and when used in 
combination with another protease inhibitor, ritonavir reduces viral metabolism and aids in viral clearance.

\section{Antivirals}

In vitro antivirals are compared to two broad-ranging medicines for the purpose of antiviral therapy such as penciclovir, ribavirin, chloroquine, nafamostat, umifenovir, darunavir, and arbidoland nitazioxanide, such as favipiravir and remdesivir. Chloroquine and remdesivir were both more effective in treating COVID-19 among the drugs investigated (Wang et al., 2020). Remdesivir is a currently improved Ebola virus adenosine analogue medication that is effective in various viruses such as SARS-CoV, MERS-CoV, and SARS-CoV-2 (Sheahan et al., 2017; Mulangu et al., 2019; Holshue et al., 2020). Remedies have now been confirmed in vitro that SARS-CoV-2 infection could be successfully controlled (Wang et al., 2020). The first anti-new coronavirus medicine to be approved on the market by the National Medical Products administration after the outbreak, was Favilavir, previously considered as capilavir. The medicine was produced and is thought to have an important role in the treatment and prevention of the epidemia by the Zhejiang Hisun Pharmaceutical Company. To date, 482 of the most regular treatments in SARS and MERS patients were ribavirin and ribavirin with different types of IFNs (Morgenstern et al., 2005; Omrani et al., 2014).

- Ribavirin is an analogue nucleoside, has a wide variety of antiviral properties through prevention of viral RNA and mRNA capping (Von Grotthuss et al., 2003). Previous studies indicated that ribavirin-alisporivir for the enhanced SARS-CoV and MERS-CoV anti-viral properties (de Wilde et al., 2017). In order to combat SARS-CoV and MERS-CoV and also SARSCoV-2, IFN, thymosin and intravenous $\alpha$-globulin were thought to improve immune system (Xie and Chen, 2020). Researchers earlier demonstrated the possibility of improving the SARS-CoV (Chu et al., 2004) and MERS-CoV findings with protease inhibitors like ritonavir and lopinavir (human Immunodeficiency Virus (HIV) (Arabi et al., 2020). Viral loads of a COVID-19 patient in Korea have been reported to be reduced significantly following lopinavir/ritonavir treatment (Lim et al., 2020). In that sequence, in February 2020 Wang and the team have evaluated the antiviral effectiveness of 5 different FDA-approved medicines: chloroquine, ribavirine, nitazoxanide, penciclovir, nafamostat and two widely used favipiravir anti-COVID-19 anti-corrosive agents. This study revealed the effective control of COVID-19 in-vitro cell culture with two medications named chloroquine and remdesivir. The drug should be tested in human patients with COVID-19 infection based on its safety profile and efficacy in other viral infections (Wang et al., 2020). Three COVID-19 infected patients in the United States tested for remdesivir during the outbreak, which revealed symptom improvements with- out significant side effects and also allowed FDA to use the product in about 250 patients. With regard to safety, a phase III clinical trial in remdesivir was announced by Gilead Sciences to demonstrate safety and effectiveness in COVID-19 infections. Gilead announced the results of the initial Phase 3 clinical trial after a preliminary investigation. During 14 days of treatment, the medicine significantly reduced mortality rate and improved 64\% of cases (Gilead, 2020). On the basis of these results, an authorization has been issued to use remdesivir for emergency use by the FDA against COVID-19, but no global complete approval has yet been provided (FDA, 2020).

- Chloroquine. The FDA had authorised the treatment of malaria, arthritis and lupus in drugs chloroquine (Solomon and Lee, 2009). Studies have also demonstrated that chloroquine is a successful candidate to treat SARS-CoV-2 (Touret and de Lamballerie, 2020). Chloroquine prevents the binding of virus cell and is involved in cellulary receptor ACE2 and SARS-CoV glycosylation, which is less efficient for ACE2-SARS-CoV interaction. In vitro confirmation has been made that chloroquine significantly inhibits the spread of SARS-CoV through interference with ACE2 in cells lines of Vero E6 (Vincent et al., 2005). (Wang et al., 2020). The People's Republic of China's National Health Commission reported the inclusion of Chloroquine as a test drug in the COVID-19 Guideline (6th edition) because of the good outcome of the preliminary clinical trials. Chloroquine is therefore considered a safer treatment option than other medications, but overdose of it could cause death toxicity (Liu et al., 2020).

- Hydroxychloroquine. Documentation indicates that chloroquine hydroxyl derivative, hydroxychloroquine, may be used for treating SARS-CoV-2 infections with a better and safer alternative to chloroquine. Moreover, animal studies show less toxicity than chloroquine (Liu et al., 2020). In an in vitro study, Liu et al. studied its antiviral activity in comparison to chloroquine in an efficacy assessment of Hydroxychloroquine against SARS-CoV-2 infections. It has been shown that Hydroxychloroquine reduces in vitro SARS-CoV-2 infection. In the plasma of infected patients, with COVID-19, higher cytokinin levels were also observed. As a result, the severity of the disease is increased. According to this study, cytokines can be reduced by serum hydroxychloroquine. The author therefore suggested that Hydroxychloroquine may be a potentially infectious candidate. But in clinical models relative to chloroquine, no evidence exists that Hydroxychloroquine is efficient in SARS-CoV-2 ( Liu et al., 2020). In addition, many companies have registered more than 300 clinical trials throughout the world in order to investigate the efficacy and safety of this medicine for COVID-19 based on encouraging preclinical data and earlier clinical data on a small population. The role of Hydroxychloroquine in respiratory viral loads in COVID-19 patients was assessed 
in an open-label non-randomized clinical study. 26 COVID-19 Hydroxychloroquine patients were treated for 10 days at $600 \mathrm{mg} /$ day. Based on their results, the viral load in most patients was removed efficiently on day 5 .

- Favipiravir sold as Avigan against COVID-19 has been found to be effective. In the clinical trial of 340 patients in Shenzhen and Wuhan city, Xinmin Zhang, Chinese Minister of Science and Technology, said that Favipiravir yielded positive results. This drug has been developed for influenza infection by Toyama Chemicals. The experimental treatment of new coronaviral infections was approved for February 2020. In the Wuhan trial, favipiravir treatment improved infection symptoms and decreased fever duration.

- Bevacizumab . A new US-FDA approval for first line treatment of metastatic colorectal cancer was obtained from Bevacizumab, a recombinant humanized monoclonal antibody against VEGF, on February 26, 2004 (Cowling and Leung, 2020). The FDA subsequently approved a number of cancers, such as lung cancer, renal cancer, cervical cancer, ovarian cancer, etc., with this product and with chemotherapy (Zhang and Zhou, 2018). Recent studies also suggest that higher blood VEGF levels in COVID-19 patients are most detrimental to COVID-19 compared to normal, pulmonary, dyspnea and acute respiratory distress. On this basis, Qilu Shandong University Hospital has also started clinical trials of this COVID-19 product (Clinical trials. gov).

- Protease inhibitors. The USFDA approved protease inhibitors for treatment of HIV and these drugs have also been previously tried in SARS-CoV. Its clinical effectiveness, however, was uncertain. The synthesis of structural and functional polyprotein such as pplab and ppla, which helps further replicate viruses, is the main responsibility of protease enzymes. Protease inhibitors such as lopinavir/ritonavir have been shown to inhibit 3-chymotrypsin activity, such as protease enzymes, which plays an important role in the replication and synthesis of critical structural proteins (Chu et al., 2004; de Wilde et al., 2014).

- Lopinavir/ritonavir has been included in many countries in its clinical guidelines for treatment for COVID-19 and by June 142020 there were 48 clinical trials worldwide (Clinicaltrial.gov.in). However, clinical trial data for the safety and effectiveness of these COVID-19 infection medicines are very restricted, as only one of them has yet been published (Cao et al. and Ivan fan-Ngai Hung et al.). In order to find out how the combination of Lopinavir and Ritonavir works, Cao and his team carried out an open-label, randomised and controlled clinical trial. They found that, in combination with standard care, there was no significant clinical improvement in the proposed combination, and that death was not reduced in comparison with the standard treatment group only. On the basis of this finding, further studies with further com- bination drugs are required to evaluate the effectiveness of the COVID-19 infection with Lopinavir and Ritonavir (Belouzard et al., 2009).

At the moment, no medicinal products for COVID-19 are approved by the FDA and the WHO, but are being investigated and hopefully will be successful soon. Current clinical studies of patients with SARS-CoV-2 reported to be efficient drug candidates to treat the infection of SARS-CoV-2 with remdesivir and hydroxychloroquine. However the efficacy and safety profile of such drugs are supported by robust clinical trial data, because only very few such studies have been reported. These studies are also required to respond to a series of questions, such as drug dose, treatment duration, defined therapeutic parameters, high-risk population identify and severe adverse properties.

\section{Convalescent Plasma or Plasma Therapy}

A simple but very efficacious method of treatment was used in patients recovering from coronavirus infection with convalescent plasma or serum and to treat very severely infected cases. A particular antibody reaction can be used in newly ill people to counteract viruses in patients suffering from a viral disease that is resolute. During the Ebola outbreaks in West Africa during 2014-2015, this method was successful (Kraft et al., 2015), as well as in the SARS-CoV (Mair-Jenkins et al., 2015) and MERS-CoV (Arabi et al., 2015). However, development of plasma convalescent therapy has partially helped in the outbreak because increase in the number of diseased patients exponentially exceeds the number of plasma donors (Rabi et al., 2020). During the outbreaks, this therapy was applied without exact vaccines or medicines (Arabi et al., 2015).

\section{Anticoagulants as Therapeutics}

- Heparin. Low molecular weight heparin (LMWH) is commonly used as a COVID-19 remedy. The bindings of spike proteins COVID-19 as well as interleukin-6 deregulation, which is increased in COVID-19 patients, were implicated (Mummery and Rider, 2000). A recent study shows how the SARSCoV-2 spike S1 (SARS-CoV-2 S1 RBD) interacts with heparin and suggests the development of Heparinbased therapy (Microft-West et al., 2020). New heparin compounds for COVID-19 are of great interest (Zhang et al., 2020).

- Dipyridamole. Dipyridamole (DIP), an antiplatelet, acts as an inhibitor of phosphodiesterase (PDE), which increases cAMP/cGMP intracellular (Gresele et al., 2011). In addition to the famous antiplatelet function, DIP can offer patients with COVID-19 potential therapeutic benefits. The clinical trials in China have shown DIP to be particularly successful in 
combating the RNA viruses, of a broad spectrum of antivirals (Xie, 2010).

- Use of ACE2 inhibitors. For entering the virus in the host cell, ACE2 receptor is required. Hemming this receptor could successfully limit the replication of viruses in the body. The DX600 inhibitor, selective ACE2 can show good results for SARS-CoV-2 infection but still has to examine its clinical importance (Huang et al., 2003).

\section{PREVENTIVE MEASURES AGAINST TRANSMISSION OF COVID-19}

The COVID-19 disease has a high rate of transmission from person to person and through diverse surfaces such as metal, cardboard, and plastic (Bedford et al., 2020). As a result, WHO and other health ministries have advocated various preventive measures across numerous nations to avoid the spread of Coronavirus (SARS-CoV-2). These are the following:

- Social distancing. People should keep at least a 3-meter distance from one another, according to WHO guidelines, to limit the risk of COVID-19 transmission from person to person. In addition, to approach the disease in the community transmission stage, large gatherings should be avoided. To prevent transmission, people who come into close touch with an infected person should be separated and quarantined for at least 14 days (Yi et al., 2020).

- Personal protective equipment (PPE). PPEs are worn by health-care workers to protect them from SARS-CoV-2 infection and prevent secondary transmission in hospitals. Breathing masks such as N95 (filters $>95$ percent of airborne particles), FFP2 (filters $>94$ percent of airborne particles), and FFP3 (filters $>99$ percent of airborne particles) should also be used by health care workers to avoid infection. To avoid reckless handling, health care professionals should receive adequate training in PPE handling. In addition, sufficient care should be taken when discarding old PPEs (Kraemer et al., 2020).

- Hand sanitizers. Individuals should clean their hands using alcohol-based sanitizers on a regular basis to avoid coronavirus illness. As a preventative strategy, washing hands with soap and water before and after meals is required (World Health Organization, 2020).

- Countrywide lockdown. Due to the pandemic catastrophe and global public health crisis, India, the world's second-largest population after China, imposed a significant countrywide lockdown in four phases from March 25th to May 31st, 2020, for a total of 68 days $(21+19+14+14)$. (To minimize the spread of infection or transmission.)

- Daily fever surveillance. In an attempt to identify suspected people with fever in general, temperature screening checkpoints have been set up at railway stations, metro stations, seaports, and airport terminals to screen all travelers using thermal scanners.

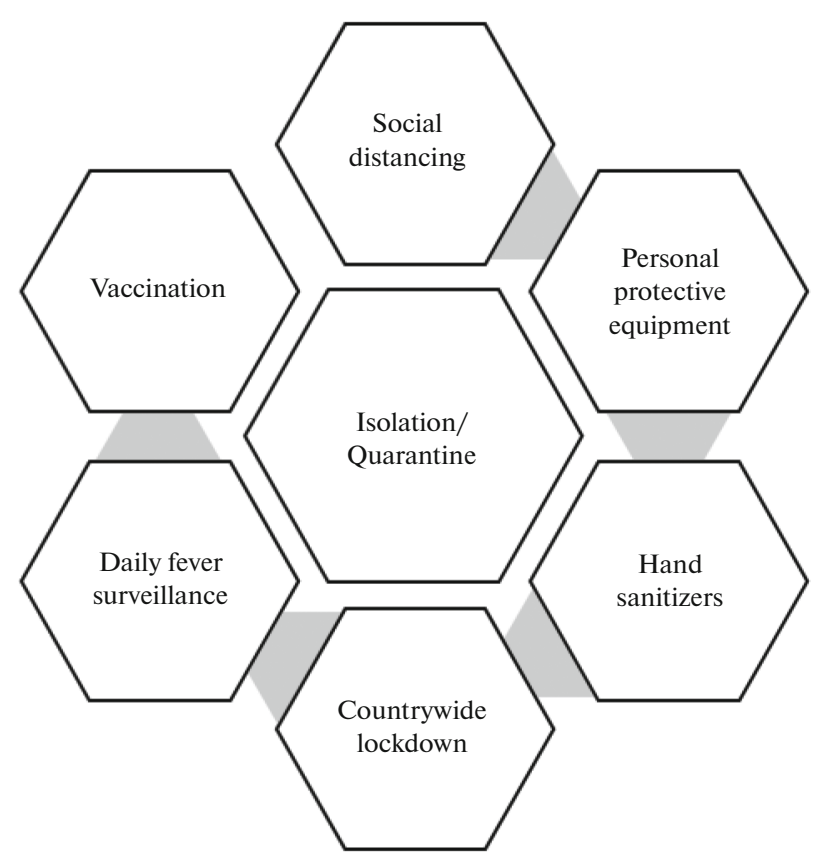

Fig. 4. Measures against transmission of COVID-19.

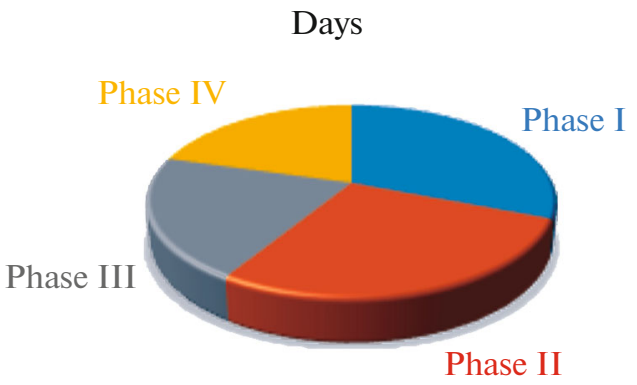

Fig. 5. Implementation of Countrywide lockdown in India.

- Isolation/Quarantine. Isolation and quarantine is a classic but highly efficient and effective measure against all hazardous epidemics. In a separate room either the suspect should be isolated in their home, i.e. quarantine, or opt for quarantine based on facilities. WHO proposed that patients who do not have causal chronic diseases (heart and lung diseases, immunodeficiency or renal failure) and who may suffer from mild isolation symptoms in the home environment (WHO, 2020d). In return, adverse cases should be hospitalized and serious cases admitted to the ICU for proper treatment and medical treatment should be admitted immediately.

- Vaccination. The need for the hour to make immunity from COVID-19 is an effective vaccine. In the meantime, the breakup of the transmission chain requires non-pharmacological measures, such as social distancing, wearing masks and practical hand hygiene. In control of the epidemics/pandemics 
caused by these exotic and highly infectious viral etiologies, vaccination is essential for antiviral treatment. The study was conducted on viruses based on liveattenuated or non-activated viruses, recombinant viral vectors, DNA, VLPs and soluble proteins. Several developers of COVID-19 leading nominee vaccines have indicated that they have applied, or are planning to apply for, emergency vaccine approval. The granting of the designation of candidate vaccinations for emergency use poses numerous ethical problems, including in the case of unblinding trials. The potential impact on other vaccine studies, risk reduction behavior, retention of the test and confidence in the vaccine. However, a vaccine stimulating a protective immune response is of concern, rather than allergic to etiology, for the most part in adverse events following immunization (AEFI). Anaphylaxis as an anaphylactic AEFI is very uncommon for the majority of vaccines with less than $1 \mathrm{dose} / \mathrm{million}$. Although there are now more than 40 different vaccine applicants, the most exciting fact is that the vaccine from Pfizer and BioNTech was the first that showed promising data on effectiveness. $90 \%$ effectiveness of the vaccine appeared. The risk of the vaccine is that it's not $100 \%$ effective and reduces its efficacy unless it is stored at precise temperatures. Issues involve vaccine management (i) vaccine storage and transport requires $70^{\circ} \mathrm{C}$ for maintaining its efficacy, (ii) vaccine administrations will be difficult, given that recipients need a booster 21 days later, and that the tracking and administration of this vaccine in a specified time frame will require significant efforts (to maximize its effectiveness). As of Jan 2021, Pfizer-BioNTech BNT162b2 vaccine \& manufacturer company with legal status, in Argentina, Bahrain, Canada, Saudi Arabia, Chile, Costa Rica, Ecuador, EU, Israel, Jordan, Kuwait, Mexico, Oman, Panama, Singapore, Switzerland, UK, USA, WHO was approved for EUA; however, the EUA status was pending in Australia, India, Japan.

Vaccines that currently have been approved for emergency use authorization (EUA) against SARSCoV-2, apart from Pfizer are:

I. ChAdOx1 (Oxford/AstraZeneca; Covishield in India),
II. Sputnik V (Gamaleya Research Inst.),

III. Covaxin (BBV152) (Bharat Biotech, India),

IV. EpiVacCorona (Federal Budgetary Research Institution State Research Ctr, Russia),

V. Moderna mRNA-1273,

VI. BBIBP-CorV (Sinopharm, Beijing Institute \& Wuhan Inst. of Biological Products),

VII. Convidicea Ad5-nCoV (CanSino Biologics, Beijing Inst. Biotech., NPO Petrovax),

VIII. CoronaVac (Sinovac, China).

\section{VACCINE CHARACTERISTICS}

Numerous technological methods (e.g., DNA, RNA, inactivated, viral vector, protein subunit) are available for the development of vaccine. Vaccine traits (e.g., dosage frequency, speed of development, scalability) depend on the type of technological method employed. Although some methods have been used previously in the development of vaccines, whereas others are newly developed. For instance, mRNA vaccines for rabies, influenza, and Zika virus have been formerly tested in animals.

\section{mRNA VACCINES}

BNT-152b2 popularly known as Pfizer is a nucleoside-modified RNA (modRNA) messenger-based vaccine encrypting an optimized SARS-CoV-2-receptor-binding (RBD) domain. It is a series of double doses with a space of 21 days. The effectiveness of the vaccine against the original SARS-CoV-2 strain was found to be 95 per cent within seven days of the second dose and there were no serious safety concerns noted.

\section{- Current status:}

Rolling Biologics License Application (BLA) submitted May 7, 2021, to FDA for full approval for individuals aged 16 years and above.

Emergency Use Authorization (EUA) has been granted in the United States for individuals aged 12 years and above,

Table 2. Features of the Vaccine Channel

\begin{tabular}{|c|c|c|c|}
\hline Vaccine type & Attributes & Doses & Producer \\
\hline mRNA & Rapid progress speed; low-to-medium production scale & 2 & $\begin{array}{l}\text { BNT-162b2 (Pfizer, BioNTech); } \\
\text { mRNA-1273 (Moderna) }\end{array}$ \\
\hline DNA & Rapid development speed; medium manufacturing scale & 2 & INO-4800 (Inovio) \\
\hline Viral vector & Intermediate growth; high engineering scale & 1 or 2 & $\begin{array}{l}\text { AZD-1222 Ad5-CoV (AstraZeneca; } \\
\text { Oxford University); } \\
\text { Ad26.COV2.S (Johnson \& Johnson) }\end{array}$ \\
\hline Protein subunit & Intermediate-to-fast development; high manufacturing scale & 2 & NVX-CoV2373 (Novavax) \\
\hline
\end{tabular}

The current status of the approved vaccines as on 10th of June 2021. 
National Institutes of Health (NIH) second phase trial of allergic reactions to vaccine in applicants with severe allergies in progress,

Complete Phase 3 trials in adults and adolescents aged 12 years and above,

In pregnant women Phase 2/3 trial started in February 2021,

Phase $1 / 2 / 3$ trials starting spring 2021 in infants and younger children aged 6 months and older.

In older adults Phase 3 trial of BNT-162b2 booster dose followed by the 20 -valent pneumococcal conjugate vaccine $(20 \mathrm{vPnC})$.

- mRNA-1273 the S-2P antigen codes for vaccine also known as Moderna. It is run in 4 weeks apart as a double-dose series. A single mRNA-1273 or mRNNA-1273.351 booster dose in previously vaccinated clinical trial participants is reported to be imparting enhanced neutralizing titers for SARSCoV-2 and 2 other alarming variants (i.e., B.1.351, P.1). The promoter dose for B.1.351 was higher than a booster mRNA-1273 for mRNA-1273, strainmatched applicants.

- Current status:

EUA in the US for aged 18 years and above,

EUA submitted June 10, 2021, for adolescents based on phase $2 / 3$ TeenCOVE trial $(n=3732)$ completed in adolescents aged 12-17 years displaying $100 \%$ efficacy after administration of 2 doses,

$\mathrm{NIH}$ phase 2 trial of allergic reactions to vaccine in applicants with severe allergies ongoing,

Complete US phase 3 trial coronavirus efficacy (COVE) in adults,

KidCOVE trial children aged 6 months and older of Phase 2/3 began in March 2021 (target enrollment 6750),

Second Phase study initiated for booster vaccine candidates,

To assess nasal viral load and shedding in university students Phase 3 trial is planned.

\section{VIRAL VECTOR VACCINES}

Ad26.COV2.S is a recombinant vector-based adenovirus vaccine type 26 (Ad26) administered as a single injection by JNJ-78436735, VAC31518; by Johnson \& Johnson. Ad26.COV2.S was reliable across race defence; age groups including older adults were studied in all variants and areas, including South Africa, where almost all COVID-19 cases (95 per cent) were due to B.1.351 SARS-CoV-2 variant infections.

- Current status:

For adults aged 18 years and above EUA in the United States.

Phase 3 trial (ENSEMBLE) in adults completed.

In pregnant women Phase 2 trial launched February 2021.
To evaluate the efficiency of 1 or 2 doses Phase 2a trial (ENSEMBLE 2) began late 2020 ENSEMBLE 2 trial expanded to include adolescents April 2021.

AZD-1222 (ChAdOx1 nCoV-19; AstraZeneca, Covishield in India). A vaccine based on vectors containing surface glycoprotein antigen (spike protein) is a replication deficient chimpanzee adenoviral. It is directed 28 days apart as a double dose series. The vaccine reinforces your immune system by producing antibodies to attack the SARS-CoV-2 virus if it infects your body later. The development of AZD-1222 was comparatively rapid compared to other viral vector vaccinations by testing for different coronavirus vaccines in 2019. The efficiency of vaccines was reported to be 76 percent following a single standard daily dose of vaccine from 22-90 day.

- Current status:

EUA submission in the United States Pending; approved for practice in United Kingdom and other countries.

Phase 3 trials completed in United States in March 2021.

In United Kingdom Phase 3 trial is planned to assess safety and immune response in children and young adults aged $6-17$ years.

However Cases of thrombosis with thrombocytopenia (TTS) with the Ad26.COV2.S (Janssen [Johnson \& Johnson]) and AZD-1222 (ChAdOx1 nCoV-19; AstraZeneca) vaccines have been also reported. The FDA temporarily paused the use of Ad26.COV2.S in mid-April 2021 to allow the CDC's Advisory Committee on Immunization Practices (ACIP) estimating rare cases of thrombosis of the brain vein sinus. ACIP reaffirmed its provisional recommendation to use the vaccine Janssen COVID-19 for all persons aged 18 years or older under FDA EUA after discussion about the benefits and risks of resuming vaccination. The EUA now warns of rare coagulation after immunization, mainly among women between 18 and 49 years of age. The risk of death, including thrombosis, and serious consequences of COVID-19 overlap the TTS potential of extremely successful vaccines.

\section{PROTEIN SUBUNIT VACCINES}

NVX-CoV2373 (Novavax) is engineered by using recombinant nanoparticle technology from the SARS-CoV-2 genetic sequence to generate the fulllength, prefusion spike (S) protein. This is united with an adjuvant (Matrix-M). Results of preclinical studies suggest that it binds efficiently with human receptors targeted by the virus. It is administered as a 2-dose series given 21 days apart. Considered efficacy original strain: $96.4 \%$.

- Current status:

Primary results published in the United Kingdom from phase 3 trial.

In South Africa primary results published from phase $2 \mathrm{~b}$. 
Table 3. Different stages of development and clinical trials, of Additional vaccine candidates

\begin{tabular}{|c|c|c|}
\hline & Vaccines & Remarks \\
\hline 1 & INO-4800 (Inovio Pharmaceuticals) & $\begin{array}{l}\text { A vaccine based upon DNA, double-dose, stable for more than } 1 \text { year at } \\
\text { room temperature; not required for frozen delivery. Continuing phase } 2 / 3 \\
\text { (INNOVATE) trial; Phases } 2 \text { for evaluating the sample of } 400 \text { contributors in } \\
\text { 2-dose regimes ( } 1 \text { or } 2 \mathrm{mg} \text { ) }\end{array}$ \\
\hline 2 & CVnCoV (CureVac) & $\begin{array}{l}\text { mRNA based, double-dose vaccine. In multiple European and Latin American } \\
\text { sites with the goal to enroll 35,000 applicants Phase 2b/3 trial (HERALD) began } \\
\text { in December } 2020 \text { of mRNA } 12-\mu \text { dose ( } 2 \text { doses on days } 1 \text { and 29). Associating } \\
\text { partners-Bayer, GlaxoSmithKline, and Novartis for the production }\end{array}$ \\
\hline 3 & $\begin{array}{l}\text { Recombinant protein adjuvanted vac- } \\
\text { cine (Sanofi and GSK) }\end{array}$ & $\begin{array}{l}\text { 95-100 percent seroconversion was observed in the interim phase } 2 \text { results } \\
(n=722) \text { after two doses, with a large level of neutralizing anti-body compa- } \\
\text { rable to natural infection. This indicates the strong potential of development } \\
\text { as a booster vaccine, which is shown by high level of neutralizing antibody } \\
\text { levels in participants following a single jab. Stage } 3 \text { trial starting with a target } \\
\text { enrollment of } 35000 \text { in Mid-2021 }\end{array}$ \\
\hline 4 & $\begin{array}{l}\text { S-Trimer with CpG } 1018 \text { adjuvanted } \\
\text { vaccine (Clover and Dynavax) }\end{array}$ & $\begin{array}{l}\text { Phase } 2 / 3 \text { trial (SPECTRA) of Clover's protein-based S-Trimer COVID-19 } \\
\text { subunit vaccine adjuvanted with Dynavax's CpG } 1018 \text { plus alum. Adminis- } \\
\text { tering } 2 \text { doses, } 21 \text { days apart trial began in March } 2021 \text { in Latin America, } \\
\text { Asia, Europe, and Africa }\end{array}$ \\
\hline 5 & $\begin{array}{l}\text { VLA2001 with CpG } 1018 \text { adjuvant } \\
\text { (Valneva and Dynavax) }\end{array}$ & $\begin{array}{l}\text { Inactivated whole virus vaccine. In the United Kingdom, Phase } 3 \text { trial (Cov- } \\
\text { Compare) will compare the immunogenicity of VLA2001 with AZD-1222 in } \\
\text { approximately } 4000 \text { adults }\end{array}$ \\
\hline 6 & $\begin{array}{l}\text { UB-612 multitope peptide-based vac- } \\
\text { cine (COVAXX [United Biomedical, } \\
\text { Inc.]) }\end{array}$ & $\begin{array}{l}\text { Embraced amino acidic sequences for the SARS-CoV-2 domain of recep- } \\
\text { tors; further formulated for memory retrieval, } t \text {-cell activation and effector } \\
\text { function, with designer Th and CTL Epitome peptides derived from the } \\
\text { membrane, S2 sub-units and nuclear protection areas of SARS-CoV- } 2 \text { struc- } \\
\text { tural proteins. Starting second phase trial in Taiwan and phase } 2 / 3 \text { trial in } \\
\text { Brazil in first quarter 2021. To form a new company, call Vaxinity to include } \\
\text { both the companies' vaccine platforms, Covaxx is amalgamating with its sis- } \\
\text { ter company (United Neuroscience) }\end{array}$ \\
\hline 7 & $\begin{array}{l}\text { HaloVax (Hoth Therapeutics; Voltron } \\
\text { Therapeutics) }\end{array}$ & $\begin{array}{l}\text { Collaboration with the Massachusetts General Hospital Vaccine and Immu- } \\
\text { notherapy Centre; use of the self-assembling vaccine platform VaxCelerate } \\
\text { provides } 1 \text { fixed immune adjuvant and } 1 \text { variable immune destination, to } \\
\text { enable speedy development }\end{array}$ \\
\hline 8 & $\begin{array}{l}\text { Nanoparticle SARS-CoV-2 vaccine } \\
\text { (Ufovax) }\end{array}$ & $\begin{array}{l}\text { Development of prototype vaccines using the technology of the platform of } \\
\text { self-assembling nanoparticle protein (1c-SapNP) }\end{array}$ \\
\hline 9 & PDA0203 (PDS Biotechnology Corp) & Utilizes Versamune T-cell-activating platform for vaccine development \\
\hline 10 & $\begin{array}{l}\text { CoVLP (Medicago and GlaxoSmith- } \\
\text { Kline) }\end{array}$ & $\begin{array}{l}\text { Combines Medicago's recombinant coronavirus virus-like particles } \\
\text { (rCoVLP) with GSK's adjuvant system. In March } 2021 \text { Phase } 3 \text { trial initiated } \\
\text { with the aim to enroll } 30,000 \text { healthy adults aged } 18-65 \text { y initially, followed } \\
\text { by individuals } 65 \text { y and older with comorbidities. Initially starting in Canada } \\
\text { and the United States the trial will take place in } 10 \text { countries }\end{array}$ \\
\hline 11 & $\begin{array}{l}\text { Covaxin (BBV152; Bharat Biotech and } \\
\text { Ocugen) }\end{array}$ & $\begin{array}{l}\text { Co-developed with Ocugen; Whole-virion inactivated COVID- } 19 \text { based vac- } \\
\text { cine candidate. Developed and manufactured in Bharat Biotech's bio-safety } \\
\text { level } 3 \text { biocontainment facility announced for the US market. In January } \\
2021 \text { Received EUA in India after a fully enrolled phase } 3 \text { trial }(n \sim 25800) \text {. In } \\
\text { India } 81 \% \text { efficacy Interim phase } 3 \text { results reported in March } 2021 \text {. The sec- } \\
\text { ond interim analysis of phase } 3 \text { results in late April } 2021 \text { found } 78 \% \text { efficacy } \\
\text { against mild-to-moderate infection and } 100 \% \text { efficacy against severe } \\
\text { COVID- } 19\end{array}$ \\
\hline
\end{tabular}


Table 3. (Contd.)

\begin{tabular}{|c|c|c|}
\hline & Vaccines & Remarks \\
\hline 12 & $\begin{array}{l}\text { Recombinant adenovirus type-5-vec- } \\
\text { tored vaccine (Ad5-vectored vaccine; } \\
\text { Sinopharm [China]) }\end{array}$ & $\begin{array}{l}\text { Approved in China and Saudi Arabia; preliminary data: } 86 \% \text { effectiveness; } \\
\text { phase } 2 \text { trial: seroconversion of neutral anticorps seen in } 59 \text { and } 47 \% \text { in } 2 \% \text {, } \\
\text { binding anticorps in } 96-97 \% \text { of participants, positive specific cell responses } \\
\text { seen in } 88-90 \% \text { of participants. Vaccines for emergency use approved by the } \\
\text { World Health Organization in May } 2021 \text { for better distribution through } \\
\text { Covax among poorer nations }\end{array}$ \\
\hline 13 & $\begin{array}{l}\text { CoronaVac (Ad5-vectored vaccine; } \\
\text { Sinovac [China]) }\end{array}$ & $\begin{array}{l}\text { Limited use in China. Interim phase } 3 \text { efficiency reports differ widely from } \\
\text { several trials. A trial in Brazil reports the efficacy of } 50-90 \% \text {. However, a } \\
\text { Turkish trial reports } 91.25 \% \text { efficacy ( } n=7371 \text {; data analysis based on } 1322 \\
\text { participants }-752 \text { vaccines and } 570 \text { placebo) }\end{array}$ \\
\hline 14 & $\begin{array}{l}\text { rAd26 (frozen) and rAd5 vector-based } \\
\text { (lyophilized) formulations (Sputnik V; } \\
\text { Moscow Gamaleya Institute) }\end{array}$ & $\begin{array}{l}\text { Approved in Russia. A gene for full-length SARS-CoV- } 2 \text { glycoprotein } \mathrm{S} \text { is car- } \\
\text { ried by each vaccine vector. The third phase trial administered } 2 \text { doses, } 21 \text { days } \\
\text { apart ( }(\mathrm{Ad} 26 \text { then rAd5) assigned in a } 3: 1 \text { ratio of vaccine }(n=16501) \text { or pla- } \\
\text { cebo }(n=5476) \text {. Interim analysis of results } 21 \text { days after the first dose (ie, day of } \\
\text { dose } 2) \text { confirms COVID-19 infection in } 0.1 \% \text { of the vaccine group compared } \\
\text { with } 1.3 \% \text { of the placebo group. Vaccine effectiveness, } 91.3 \%\end{array}$ \\
\hline 15 & $\begin{array}{l}\text { hAd5 T-cell (ImmunityBio and } \\
\text { NantKwest) }\end{array}$ & $\begin{array}{l}\text { Continuing Phase } 1 \text { study; targets inner nucleocapsid }(\mathrm{N}) \text { and outer spike } \\
\text { (S), which have been developed for the activation of SARS-CoV-2 T cells } \\
\text { and antibodies. } \\
\text { These dual structures offer a possibility for the vaccine candidate to provide } \\
\text { durable cell-medicated immunity with powerful antibody stimulation for } \\
\text { patients with both S and N proteins. } \\
\text { Phase } 1 \text { study with a room-temperature oral or sublingual booster has been } \\
\text { expanded to include the initial SC primary Vaccine to induce full immune } \\
\text { protection and to produce both systemic and mucous antibodies }\end{array}$ \\
\hline 16 & MRT5500 (Sanofi and Translate Bio) & $\begin{array}{l}\text { mRNA-based vaccine candidate; preclinical evaluation demonstrated favor- } \\
\text { able ability to elicit neutralizing antibodies using a 2-dose schedule adminis- } \\
\text { tered } 3 \text { week apart in Fall } 2020 \text {. Despite this, Sanofi announced the vaccine } \\
\text { will not be ready to start clinical trials until the second half of } 2021 \text { and it } \\
\text { could be of use at a later stage against variants }\end{array}$ \\
\hline 17 & $\begin{array}{l}\text { AG0302-COVID19 (AnGes and Brick- } \\
\text { ell Biotech) }\end{array}$ & $\begin{array}{l}\text { Adjuvanted DNA vaccine in phase } 1 / 2 \text { study in Japan; data readouts pro- } \\
\text { jected in Q1 2021; intent to follow with stage } 3 \text { trials in the United States and } \\
\text { South America }\end{array}$ \\
\hline 18 & $\begin{array}{l}\text { SARS-CoV-2 spike ferritin nanoparticle } \\
\text { (spFN) vaccine with ALFQ adjuvant } \\
\text { (Walter Reed Army Institute of Research) }\end{array}$ & $\begin{array}{l}\text { Phase } 1 \text { study launched April 1, 2021. A preclinical trial in monkeys showed } \\
2 \text {-dose vaccines delivered high antibody levels. Development plans include a } \\
\text { new vaccine version with proteins from other coronaviruses }\end{array}$ \\
\hline 19 & $\begin{array}{l}\text { EPV-CoV-19 (EpiVax) Subunit, T-cell } \\
\text { epitope-directed vaccine }\end{array}$ & $\begin{array}{l}\text { Preclinical validation studies completed. Clinical trial anticipated in early } \\
2021 . \\
\text { Discontinued vaccine development }\end{array}$ \\
\hline 20 & $\begin{array}{l}\text { Vaccine candidates V590 and V591 } \\
\text { (Merck) V590 and V591 (subunit vac- } \\
\text { cines) }\end{array}$ & $\begin{array}{l}\text { Phase } 1 \text { studies displayed immune responses were inferior to natural infec- } \\
\text { tion and those reported for other SARS-CoV-2 vaccines }\end{array}$ \\
\hline
\end{tabular}

Phase 3 trial (PREVENT-19) in the United States and Mexico; estimated enrollment of 30000 completed in mid-February 2021.

To ensure all participants receive vaccine crossover studies initiated in ongoing trials in South Africa, the United Kingdom, and the United States in March/April 2021.
With the enrollment goal of 3000 across 75 US sites trial in adolescents aged 12-17 years started May 2021.

\section{VIRAL VARIANTS AND VACCINES}

Viral mutations may naturally befall anywhere in the SARS-CoV-2 genome. Unlike the human DNA genome, which is sluggish to mutate, RNA viruses are 
able to mutate readily and quickly. Variants of concern (VOCs) might diminish vaccine effectiveness, which may be evident by a high number of vaccine breakthrough cases or a very low vaccine-induced protection against severe disease. The CDC tracks variant proportions in the United States and estimated that the B.1.1.7 variant (first spotted in the United Kingdom) accounted for over $27 \%$ of cases from January 2 to March 13, 2021. On April 7, 2021, the CDC announced B.1.1.7 as the dominant strain circulating in the United States.

Heightened genomic surveillance in some countries has detected other VOCs which include B.1.351 (501Y.V2) first detected in South Africa and B.1.1.28 (renamed P.1) (501Y.V3), which was detected in routine screening at the Tokyo airport in 4 travelers from Brazil. A change of the B.1.1.7 variant that includes the E484K mutation (B.1.1.7+E484K) which was discovered in early 2021 that advances these concerns. The CDC is also tracing VOCs B.1.427 and B.1.429, which emerged in California. However, another study suggests that antibodies elicited by primary infection and by the BNT162b2 mRNA vaccine are likely to maintain protective efficacy against B.1.1.7 and most other variants, but that the partial confrontation of the virus with the B.1.351 spike protein could render some individuals less well protected, supporting a rationale for the development of modified vaccines containing the E484K mutation.

The latest Delta variant (B.1.671.2) has rapidly spread in India is emerging in the United States in mid-2021. It turns out to be the chief variant in the United Kingdom during Spring 2021. Edra et al. (2021) found that this variant is $6-8$ fold more resistant to neutralization by sera from COVID-19 convalescent and mRNA vaccinated individuals. However, a study completed by Public Health England found the BNT162b2 vaccine was reduced from $93.4 \%$ with the B.1.1.7 variant to $87.9 \%$ for the Delta variant 2 weeks after the administration of the second dose.

A slightly decreased neutralization is not considered to be clinically significant regarding vaccine efficacy, owing to the very high efficacy of each mRNA vaccine (i.e., approximately $95 \%$ ) to the Wuhan reference viral strain. A study in the United Kingdom between October 1, 2020, and January 14, 2021, determine the efficacy of AZD-1222 against the B.1.1.7 variant is similar to the efficacy of the vaccine against other lineages.

\section{COMPLIANCE WITH ETHICAL STANDARDS}

Conflict of interests. The authors declare that they have no conflicts of interest.

Statement on the welfare of humans or animals. This article does not contain any studies involving humans or animals performed by any of the authors.

\section{REFERENCES}

A controlled phase $2 / 3$ study of adjuvanted recombinant SRS-CoV-2 trimeric S-protein vaccine (SCB-2019) for the prevention of COVID-19, 2021. https://www.clinicaltrials.gov/ct2/show/NCT04672395. Accessed April 30, 2021.

Adhikari, S.P., Meng, S., Wu, Y.J., Mao, Y.P., Ye, R.X., Wang, Q.Z., Sun, C., Sylvia, S., Rozelle, S., Raat, H., and Zhou, H., Epidemiology, causes, clinical manifestation and diagnosis, prevention and control of coronavirus disease (COVID-19) during the early outbreak period: a scoping review, Infect. Dis. Poverty, 2020, vol. 9, p. 29.

Amit, S., Regev-Yochay, G., Afek, A., Kreiss, Y., and Leshem, E., Early rate reductions of SARS-CoV-2 infection and COVID-19 in BNT162b2 vaccine recipients, Lancet, 2021, vol. 397, no. 10277, pp. 875-877.

Andersen, K.G., Rambaut, A., Lipkin, W.I., Holmes, E.C., and Garry, R.F., The proximal origin of SARS-CoV-2, Nat. Med., 2020, vol. 26, pp. 450-452.

Anderson, R.M., Heesterbeek, H., Klinkenberg, D., and Hollingsworth, T.D., How will country-based mitigation measures influence the course of the COVID-19 epidemic? Lancet, 2020, vol. 395, pp. 931-934.

Angeletti, S., Benvenuto, D., Bianchi, M., Giovanetti, M., Pascarella, S., and Ciccozzi, M., COVID-2019: the role of the nsp2 and nsp3 in its pathogenesis, J. Med. Virol., 2020, vol. 92, no. 6, pp. 584-588.

AnGes and Brickell Biotech announce a collaboration agreement for the development of a novel DNA vaccine candidate for COVID-19 in the US, Brickell Biotech, 2020. https://ir.brickellbio.com/news/detail/35/anges-and-brickell-biotech-announce-a-collaboration.

Arabi, Y., Balkhy, H., Hajeer, A.H., Bouchama, A., Hayden, F.G., Al-Omari, A., et al., Feasibility, safety, clinical, and laboratory effects of convalescent plasma therapy for patients with Middle East respiratory syndrome coronavirus infection: a study protocol, SpringerPlus, 2015, vol. 4, p. 709.

A study to determine the safety and efficacy of SARS-CoV-2 mRNA vaccine $\mathrm{CVmCoV}$ in adults for COVID-19, 2021. https://www.clinicaltrials.gov/ct2/show/NCT04652102. Accessed April 30, 2021.

A study to evaluate the safety, tolerability, and immunogenicity of UB-612 COVID-19 vaccine, 2020. https://www.clinicaltrials.gov/ct2/show/NCT04545749. Accessed December 14, 2020.

HaloVax-VaxCelerate, Hoth Therapeutics. https://hoththerapeutics.com/pipeline/halo-vax/. Accessed November 21, 2020.

Baden, R.L., El Sahly, H.M., Essink, B., et al., Efficacy and safety of the mRNA-1273 SARS-CoV-2 vaccine, N. Engl. J. Med., 2021, vol. 384, no. 5, pp. 403-416.

Bedford, J., Enria, D., Giesecke, J., Heymann, D.L., Ihekweazu, C., Kobinger, G., Lane, H.C., Memish, Z., Oh, M.-D., Sall, A.A., Schuchat, A., Ungchusak, K., and Wieler, L.H., COVID-19: towards controlling of a pandemic, Lancet, 2020, vol. 395, pp. 1015-1018.

Belouzard, S., Chu, V.C., and Whittaker, G.R., Activation of the SARS coronavirus spike protein via sequential proteolytic cleavage at two distinct sites, Proc. Natl. Acad. Sci. U.S.A., 2009, vol. 106, pp. 5871-5876. 
Berry, M., Gamieldien, J., and Fielding, B.C., Identification of new respiratory viruses in the new millennium, Viruses, 2015, vol. 7, pp. 996-1019.

Bonilla-Aldana, D.K., Holguin-Rivera, Y., Cortes-Bonilla, I., Cardona-Trujillo, M.C., Garcia-Barco, A., BedoyaArias, H.A., Rabaan, A.A., Sah, R., and RodriguezMorales, A.J., Coronavirus infections reported by ProMED, February 2000-January 2020, Travel Med. Infect. Dis., 2020, vol. 35, art. ID 101575.

Cameron, M.J., Bermejo-Martin, J.F., Danesh, A., Muller, M.P., and Kelvin, D.J., Human immunopathogenesis of severe acute respiratory syndrome (SARS), Virus Res., 2008, vol. 133, pp. 13-19.

Cascella, M., Rajnik, M., Cuomo, A., Dulebohn, S.C., and Di Napoli, R., Features, Evaluation and Treatment Coronavirus (COVID-19), Treasure Island, FL: Stat Pearls, 2020.

Chen, N., Zhou, M., Dong, X., Qu, J., Gong, F., Han, Y., et al., Epidemiological and clinical characteristics of 99 cases of 2019 novel coronavirus pneumonia in Wuhan, China: a descriptive study, Lancet, 2020a, vol. 395, pp. 507-513.

Chen, Z., Tong, L., Zhou, Y., Hua, C., Wang, W., Fu, J., et al., Childhood COVID-19: a multicentre retrospective study, Clin. Microbiol. Infect., 2020b, vol. 26, no. 9, p. 1260. https://doi.org/10.1016/j.cmi.2020.06.015

Chu, C.M., Cheng, V.C., Hung, I.F., Wong, M.M., Chan, K.H., Chan, K.S., et al., Role of lopinavir/ritonavir in the treatment of SARS: initial virological and clinical findings, Thorax, 2004, vol. 59, pp. 252-256.

Coronavirus (COVID-19): Managing Stress and Anxiety, Melbourne: Univ. of Melbourne, 2020.

COVID-19 subcutaneously and orally administered supplemental vaccine boost to enhance $T$ cell protection in those who have already received EUA S-based vaccines, 2021. https://www.clinicaltrials.gov/ct2/show/ NCT04845191. Accessed April 29, 2021.

Cowling, B.J. and Leung, G.M., Epidemiological research priorities for public health control of the ongoing global novel coronavirus (2019-nCoV) outbreak, Eurosurveillance, 2020, vol. 25, no. 6, art. ID 2000110.

Cui, J., Li, F., and Shi, Z.L., Origin and evolution of pathogenic coronaviruses, Nat. Rev. Microbiol., 2019, vol. 17, pp. 181-192.

de Wilde, A.H., Falzarano, D., Zevenhoven-Dobbe, J.C., Beugeling, C., Fett, C., Martellaro, C., et al., Alisporivir inhibits MERS- and SARS-coronavirus replication in cell culture, but not SARS-coronavirus infection in a mouse model, Virus Res., 2017, vol. 228, pp. 7-13.

de Wit, E., van Doremalen, N., Falzarano, D., and Munster, V.J., SARS and MERS: recent insights into emerging coronaviruses, Nat. Rev. Microbiol., 2016, vol. 14, pp. 523-534.

Dhama, K., Sharun, K., Tiwari, R., Dadar, M., Malik, Y.S., Singh, K.P., et al., COVID-19, an emerging coronavirus infection: advances and prospects in designing and developing vaccines, immunotherapeutics, and therapeutics, Hum. Vaccine Immunother., 2020, vol. 16, no. 6 , pp. $1232-1238$.

Doria-Rose, N., Suthar, M.S., Makowski, M., et al., Antibody persistence through 6 months after the second dose of mRNA-1273 vaccine for Covid-19, N. Engl. J. Med., 2021, vol. 384, pp. 2259-2261.
Du, L., He, Y., Zhou, Y., Liu, S., Zheng, B.J., and Jiang, S., The spike protein of SARS-CoV-a target for vaccine and therapeutic development, Nat. Rev. Microbiol., 2009, vol. 7, pp. 226-236.

Edara, V.V., Lai, L., Sahoo, M.K., Floyd, K., Sibai, M., Solis, D., et al., Infection and vaccine-induced neutralizing antibody responses to the SARS-CoV-2 B.1.617 variant, N. Engl. J. Med., 2021, vol. 385, pp. 664-666.

Fehr, A.R. and Perlman, S., Coronaviruses: an overview of their replication and pathogenesis, Methods Mol. Biol., 2015, vol. 1282, pp. 1-23.

Ganesh, B., Rajakumar, T., Malathi, M., Manikandan, N., Nagaraj, J., Santhakumar, A., Elangovan, A., and Malik, Y.S., Epidemiology and pathobiology of SARSCoV-2 (COVID-19) in comparison with SARS, MERS: An updated overview of current knowledge and future perspectives, Clin. Epidemiol. Global Health, 2021, vol. 10, art. ID 100694. https://doi.org/10.1016/j.cegh.2020.100694

Galloway, S.E., Paul, P., MacCannell, D.R., Johansson, M.A., Brooks, J.T., MacNeil, A., et al., Emergence of SARSCoV-2 B.1.1.7 lineage-United States, December 29, 2020-January 12, 2021, Morb. Mortal. Wkly. Rep., 2021, vol. 70, no. 3, pp. 95-99.

Gorbalenya, A.E., Baker, S.C., Baric, R.S., de Groot, R.J., Drosten, C., Gulyaeva, A.A., et al., The species Severe acute respiratory syndrome-related coronavirus: classifying 2019-nCoV and naming it SARS-CoV-2, Nat. Microbiol., 2020, vol. 5, pp. 536-544.

Gresele, P., Momi, S., and Falcinelli, E., Anti-platelet therapy: phosphodiesterase inhibitors, Br. J. Clin. Pharmacol., 2011, vol. 72, pp. 634-646.

Guan, Y., Zheng, B.J., He, Y.Q., Liu, X.L., Zhuang, Z.X., Cheung, C.L., et al., Isolation and characterization of viruses related to the SARS coronavirus from animals in southern China, Science, 2003, vol. 302, pp. 276-278.

Guo, Y.R., Cao, Q.D., Hong, Z.S., Tan, Y.Y., Chen, S.D., Jin, H.J., et al., The origin, transmission and clinical therapies on coronavirus disease 2019 (COVID-19) outbreak-an update on the status, Mil. Med. Res., 2020, vol. 7, p. 11.

Hall, M.W., Joshi, I., Leal, L., and Ooi, E.E., Immune modulation in COVID-19: strategic considerations for personalized therapeutic intervention, Clin. Infect. Dis., 2020, art. ID ciaa 904.

Holshue, M.L., De Bolt, C., Lindquist, S., Lofy, K.H., Wiesman, J., Bruce, H., et al., First case of 2019 novel coronavirus in the United States, N. Engl. J. Med., 2020, vol. 382, pp. 929-936.

Huang, C., Wang, Y., Li, X., Ren, L., Zhao, J., Hu, Y., et al., Clinical features of patients infected with 2019 novel coronavirus in Wuhan, China, Lancet, 2020, vol. 395, pp. 497-506.

Hulswit, R.J.G., Lang, Y., Bakkers, M.J.G., Li, W., Li, Z., Schouten, A., Ophorst, B., van Kuppeveld, F.J.M., Boons, G.-J., Bosch, B.-J., Huizinga, E.G., and de Groot, R.J., Human coronaviruses OC43 and HKU1 bind to 9-O-acetylated sialic acids via a conserved receptor-binding site in spike protein domain A, Proc. Natl. Acad. Sci. U.S.A., 2019, vol. 116, pp. 2681-2690.

Imai, Y., Kuba, K., Rao, S., Huan, Y., Guo, F., Guan, B., Yang, P., Sarao, R., Wada, T., Leong-Poi, H., Crackower, M.A., Fukamizu, A., Hui, C.C., Hein, L., Uhlig, S., et al., Angiotensin-converting enzyme 2 protects from 
severe acute lung failure, Nature, 2005, vol. 436, pp. 112-116.

Jeyanathan, M., Afkhami, S., Smaill, F., Miller, M.S., Lichty, B.D., and Xing, Z., Immunological considerations for COVID-19 vaccine strategies, Nat. Rev. Immunol., 2020, vol. 20, no. 10, pp. 615-632.

Keech, C., Albert, G., Cho, I., Robertson, A., Reed, P., Neal, S., et al., Phase 1-2 trial of a SARS-CoV-2 recombinant spike protein nanoparticle vaccine, N. Engl. J. Med., 2020, vol. 383, no. 24, pp. 2320-2332.

Kim, E., Erdos, G., Huang, S., Kenniston, T.W., Balmert, S.C., Carey, C.D., et al., Microneedle array delivered recombinant coronavirus vaccines: immunogenicity and rapid translational development, EBioMedicine, 2020, vol. 55, art. ID 102743.

Koirala, A., Joo, Y.J., Khatami, A., Chiu, C., and Britton, P.N., Vaccines for COVID-19: the current state of play, Paediatr. Respir. Rev., 2020, vol. 35, pp. 43-49.

Kraft, C.S., Hewlett, A.L., Koepsell, S., Winkler, A.M., Kratochvil, C.J., Larson, L., et al., The use of TKM100802 and convalescent plasma in 2 patients with Ebola virus disease in the United States, Clin. Infect. Dis., 2015, vol. 61, pp. 496-502.

Kuba, K., Imai, Y., Rao, S., Gao, H., Guo, F., Guan, B., et al., A crucial role of angiotensin converting enzyme 2 (ACE2) in SARS coronavirus-induced lung injury, Nat. Med., 2005, vol. 11, pp. 875-879.

Lai, C.C., Shih, T.P., Ko, W.C., Tang, H.J., and Hsueh, P.R., Severe acute respiratory syndrome coronavirus 2 (SARS-CoV-2) and coronavirus disease-2019 (COVID-19): the epidemic and the challenges, Int. J. Antimicrob. Agents, 2020b, vol. 55, art. ID 105924.

Lee, I.K., Wang, C.C., Lin, M.C., Kung, C.T., Lan, K.C., and Lee, C.T., Effective strategies to prevent coronavirus disease-2019 (COVID-19) outbreak in hospital, $J$. Hosp. Infect., 2020, vol. 105, no. 1, pp. 102-103. https://doi.org/10.1016/j.jhin.2020.02.022

Lam, T.T., Shum, M.H., Zhu, H.C., Tong, Y.G., Ni, X.B., Liao, Y.S., et al., Identifying 660 SARS-CoV-2 related coronaviruses in Malayan pangolins, Nature, 2020, vol. 583 , no. 7815 , pp. $282-285$. https://doi.org/10.1038/s41586-020-2169-0

Logunov, D.Y., Dolzhikova, I.V., Shcheblyakov, D.V., Tukhvatullin, A.I., Zubkova, O.V., Dzharullaeva, A.S., et al., Safety and efficacy of an rAd 26 and rAd5 vectorbased heterologous prime-boost COVID-19 vaccine: an interim analysis of a randomized controlled phase 3 trial in Russia, Lancet, 2021, vol. 397, no. 10275, pp. 671-681.

Li, X., Wang, W., Zhao, X., Zai, J., Zhao, Q., Li, Y., et al., Transmission dynamics and evolutionary history of 2019-nCoV, J. Med. Virol., 2020, vol. 92, pp. 501-511.

Lim, J., Jeon, S., Shin, H.Y., Kim, M.J., Seong, Y.M., Lee, W.J., et al., Case of the index patient who caused tertiary transmission of COVID-19 infection in Korea: the application of Lopinavir/Ritonavir for the treatment of COVID-19 infected pneumonia monitored by quantitative RT-PCR, J. Korean Med. Sci., 2020, vol. 35 , p. e79.

Lippi, G. and Plebani, M., The novel coronavirus (2019$\mathrm{nCoV}$ ) outbreak: think the unthinkable and be prepared to face the challenge, Diagnosis (Berlin), 2020, vol. 7, no. 2 , pp. $79-81$.

https://doi.org/10.1515/dx-2020-0015
Liu, Y., Liu, J., Xia, H., Zhang, X., Fontes-Garfias, C.R., Swanson, K.A., et al., Neutralizing activity of BNT162b2-elicited serum-preliminary report, N. Engl. J. Med., 2021, vol. 384, pp. 1466-1468.

Lu, H., Stratton, C.W., and Tang, Y.W., Outbreak of pneumonia of unknown etiology in Wuhan, China: the mystery and the miracle, J. Med. Virol., 2020, vol. 92, pp. 401-402.

Lurie, N., Saville, M., Hatchett, R., and Halton, J., Developing Covid-19 vaccines at pandemic speed, N. Engl. J. Med., 2020, vol. 382, no. 21, pp. 1969-1973.

MacNeil, J.R., Su, J.R., Broder, K.R., Guh, A.Y., Gargano, J.W., Wallace, M., et al., Updated recommendations from the advisory committee on immunization practices for use of the Janssen (Johnson \& Johnson) COVID-19 vaccine after reports of thrombosis with thrombocytopenia syndrome among vaccine recipients-United States, April 2021, Morb. Mortal. Wkly. Rep., 2021, vol. 70, no. 17, pp. 651-656.

Mair-Jenkins, J., Saavedra-Campos, M., Baillie, J.K., Cleary, P., Khaw, F.M., Lim, W.S., et al., The effectiveness of convalescent plasma and hyperimmune immunoglobulin for the treatment of severe acute respiratory infections of viral etiology: a systematic review and exploratory meta-analysis, J. Infect. Dis., 2015, vol. 211, pp. 80-90.

Medicago and GSK announce start of phase 2/3 clinical trials of adjuvanted COVID-19 vaccine candidate, Medicago, 2020. https://www.medicago.com/en/newsroom/medicago-and-gsk-announce-start-of-phase-23-clinical-trials-of-adjuvanted-covid-19-vaccine-candidate.

Merck discontinues development of SARS-CoV2/COVID-19 vaccine candidates; continues development of two investigational therapeutic candidates, Merck, 2020. https://www.merck.com/news/merckdiscontinues-development-of-sars-cov-2-covid-19vaccine-candidates-continues-development-of-twoinvestigational-therapeutic-candidates/.

Microft-West, C., Su, D., Elli, S., Guimond, S., Miller, G., Turnbull, J., et al., The 2019 coronavirus (SARS-CoV2) surface protein (spike) $\mathrm{S} 1$ receptor binding domain undergoes conformational change upon heparin binding, BioRxiv, 2020.

https://doi.org/10.1101/2020.02.29.971093

Moderna announces positive initial booster data against SARS-CoV-2 variants of concern. Moderna, 2021. https://investors.modernatx.com/news-releases/newsrelease-details/moderna-announces-positive-initialbooster-data-against-sars-cov.

Moderna provides clinical and supply updates on COVID19 vaccine program ahead of 2 nd annual vaccines day, Moderna, 2021. https://investors.modernatx.com/news-releases/news-release-details/modernaprovides-clinical-and-supply-updates-covid-19-vaccine.

Morgenstern, B., Michaelis, M., Baer, P.C., Doerr, H.W., and Cinatl, J., Jr., Ribavirin and interferon beta synergistically inhibit SARS-associated coronavirus replication in animal and human cell lines, Biochem. Biophys. Res. Commun., 2005, vol. 326, pp. 905-908.

Muik, A., Wallisch, A.K., Sänger, B., Swanson, K.A., Mühl, J., Chen, W., et al., Neutralization of SARSCoV-2 lineage B.1.1.7 pseudovirus by BNT162b2 vaccine-elicited human sera, Science, 2021, vol. 371, no. 6534 , pp. $1152-1153$. 
Mulangu, S., Dodd, L.E., Davey, R.T., Jr., Tshiani Mbaya, O., Proschan, M., Mukadi, D., et al., A randomized, controlled trial of Ebola virus disease therapeutics, N. Engl. J. Med., 2019, vol. 381, pp. 2293-2303.

Mummery, R.S. and Rider, C.C., Characterization of the heparin-binding properties of IL-6, J. Immunol., 2000, vol. 165 , pp. $5671-5679$.

Novavax confirms high levels of efficacy against original and variant COVID-19 strains in United Kingdom and South Africa trials, Novavax, 2021. https://ir.novavax.com/news-releases/news-releasedetails/novavax-confirms-high-levels-efficacy-againstoriginal-and- 0 .

Ocugen's COVID-19 vaccine co-development partner, Bharat Biotech, shares second interim results demonstrating $100 \%$ protection against severe disease including hospitalization, Ocugen, 2021. https://ir.ocugen.com/news-releases/news-release-details/ocugenscovid-19-vaccine-co-development-partner-bharatbiotech-0.

Omrani, A.S., Saad, M.M., Baig, K., Bahloul, A., AbdulMatin, M., Alaidaroos, A.Y., et al., Ribavirin and interferon alfa-2a for severe Middle East respiratory syndrome coronavirus infection: a retrospective cohort study, Lancet Infect. Dis., 2014, vol. 14, pp. 1090-1095.

Padron-Regalado, E., Vaccines for SARS-CoV-2: lessons from other coronavirus strains, Infect. Dis. Ther., 2020, vol. 9, pp. 1-20.

Park, Y.-J., Walls, A.C., Wang, Z., Sauer, M.M., Li, W., Tortorici, M.A., Bosch, B.-J., DiMaio, F., and Veesler, D., Structures of MERS-CoV spike glycoprotein in complex with sialoside attachment receptors, Nat. Struct. Mol. Biol., 2019, vol. 26, pp. 1151-1157.

PDS pipeline overview: infectious disease (PDS0203), PDS Biotechnology. https://www.pdsbiotech.com/pipeline/infectious-disease. Accessed November 21, 2020.

Pfizer and BioNTech confirm high efficacy and no serious safety concerns through up to 6 months following second dose in updated topline analysis of landmark COVID-19 vaccine study, Pfizer, 2021. https://www.pfizer.com/news/press-release/press-releasedetail/pfizer-and-biontech-confirm-high-efficacy-andno-serious.

Piecemeal data releases threaten to undermine Sinovac's COVID-19 vaccine, Reuters, 2020. https://www.reuters.com/article/us-health-coronavirus-sinovac/piecemeal-data-releases-threaten-to-undermine-sinovacscovid-19-vaccine-idUSKBN2920QQ.

Polack, F.P., Thomas, S.J., Kitchin, N., et al., Safety and efficacy of the BNT162b2 mRNA Covid-19 vaccine, $N$. Engl. J. Med., 2020, vol. 383, no. 27, pp. 2603-2615.

Prompetchara, E., Ketloy, C., and Palaga, T., Immune responses in COVID-19 and potential vaccines: lessons learned from SARS and MERS epidemic, Asian Pac. J. Allergy Immunol., 2020, vol. 38, pp. 1-9.

Rabi, F.A., Al Zoubi, M.S., Kasasbeh, G.A., Salameh, D.M., and Al-Nasser, A.D., SARS-CoV-2 and coronavirus disease 2019: what we know so far, Pathogens, 2020, vol. 9, p. E231.

Robbins, R. and Mueller, B., After admitting mistake, AstraZeneca faces difficult questions about its vaccine, New York Times, 2020, Nov. 25. https://www.nytimes.com/2020/11/25/business/coronavirus-vaccineastrazeneca-oxford.html.
Rouquet, P., Froment, J.M., Bermejo, M., Kilbourn, A., Karesh, W., Reed, P., et al., Wild animal mortality monitoring and human Ebola outbreaks, Gabon and Republic of Congo, 2001-2003, Emerg. Infect. Dis., 2005, vol. 11, pp. 283-290.

Sadoff, J., Gray, G., Vandebosch, A., et al., Safety and efficacy of single-dose Ad26.COV2.S vaccine against Covid-19, N. Engl. J. Med., 2021, vol. 384, pp. 21872201.

Safety and immunogenicity of AdCOVID in Healthy Adults (COVID-19 vaccine study), 2021. https://www.clinicaltrials.gov/ct2/show/NCT04679909. Accessed April 29, 2021.

Safety, immunogenicity, and efficacy of INO-4800 for COVID-19 in healthy seronegative adults at high risk of SARS-CoV-2 exposure, 2020. https://clinicaltrials.gov/ct2/show/NCT04642638. Accessed December 9, 2020.

Sanofi and GSK COVID-19 vaccine candidate demonstrates strong immune responses across all adult age groups in phase 2 trial, Sanofi, 2021. https://www.sanofi.com/en/media-room/press-releases/2021/202105-17-07-30-00-2230312.

Sanofi's mRNA COVID-19 vaccine candidate not ready this year, Reuters, 2021. https://www.reuters.com/article/uk-health-coronavirus-sanofi-vaccines-idUKKBN2AD0PT.

SARS-CoV-2 spike ferritin nanoparticle ( $\mathrm{spFN}$ ) vaccine with ALFQ adjuvant for prevention of COVID-19 in healthy adults, 2021. https://clinicaltrials.gov/ct2/show/NCT04784767. Accessed April 5, 2021.

Schoeman, D. and Fielding, B.C., Coronavirus envelope protein: current knowledge, Virol. J., 2019, vol. 16, p. 69

Shaik, K.M., Sarmah, B., Wadekar, G.S., and Kumar, P., Regulatory updates and analytical methodologies for nitrosamine impurities detection in sartans, ranitidine, nizatidine and metformin along with sample preparation techniques, Crit. Rev. Anal. Chem., 2020. https://doi.org/10.1080/10408347.2020.1788375

Sheahan, T.P., Sims, A.C., Graham, R.L., Menachery, V.D., Gralinski, L.E., Case, J.B., et al., Broad-spectrum antiviral GS-5734 inhibits both epidemic and zoonotic coronaviruses, Sci. Transl. Med., 2017, vol. 9, p. eaal3653.

Skariyachan, S., Challapilli, S.B., Packirisamy, S., Kumargowda, S.T., and Sridhar, V.S., Recent aspects on the pathogenesis mechanism, animal models and novel therapeutic interventions for Middle East respiratory syndrome coronavirus infections, Front. Microbiol., 2019, vol. 10, p. 569.

Solomon, V.R. and Lee, H., Chloroquine and its analogs: a new promise of an old drug for effective and safe cancer therapies, Eur. J. Pharmacol., 2009, vol. 625, pp. 220233.

Su, S., Wong, G., Shi, W., Liu, J., Lai, A.C.K., Zhou, J., Liu, W., Bi, Y., and Gao, G.F., Epidemiology, genetic recombination, and pathogenesis of coronaviruses, Trends Microbiol., 2016, vol. 24, pp. 490-502.

Song, Z., Xu, Y., Bao, L., Zhang, L., Yu, P., Qu, Y., et al., From SARS to MERS, thrusting coronaviruses into the spotlight, Viruses, 2019, vol. 11, p. 59.

Thanh Le, T., Andreadakis, Z., Kumar, A., Gómez Román, R., Tollefsen, S., Saville, M., et al., The COVID-19 vaccine development landscape, Nat. Rev. Drug Discovery, 2020, vol. 19, no. 5, pp. 305-306. 
Turner, P.J., Ansotegui, I.J., Campbell, D.E., Cardona, V., Ebisawa, M., El-Gamal, Y., Fineman, S., Geller, M., Gonzalez-Estrada, A., Greenberger, P.A., Leung, A.S.Y., Levin, M.E., Muraro, A., Sánchez Borges, M., Senna, G., et al., COVID-19 vaccine-associated anaphylaxis: a statement of the World Allergy Organization Anaphylaxis Committee, World Allergy Organ. J., 2021, vol. 14, no. 2 , art. ID 100517.

https://doi.org/10.1016/j.waojou.2021.100517

Ufovax announces its self-assembling nanoparticles as the next-generation vaccine solution for COVID-19, Ufovax, 2020. https://www.ufovax.com/ufovax-announces-its-self-assembling-nanoparticles-as-the-next-generation-vaccine-solution-for-covid-19/.

Valneva initiates phase 3 clinical trial for its inactivated, adjuvanted COVID-19 vaccine candidate, VLA2001, Valneva, 2021. https://valneva.com/press-release/valneva-initiates-phase-3-clinical-trial-for-its-inactivatedadjuvanted-covid-19-vaccine-candidate-vla2001/.

Vaxart to present at the World Vaccine Congress Washington 2021, Vaxart oral COVID-19 vaccine: hold the ice and the needles. Vaxart, 2021. https://investors.vaxart.com/news-releases/news-release-details/vaxartpresent-world-vaccine-congress-washington-2021.

Vincent, M.J., Bergeron, E., Benjannet, S., Erickson, B.R., Rollin, P.E., Ksiazek, T.G., et al., Chloroquine is a potent inhibitor of SARS coronavirus infection and spread, Virol. J., 2005, vol. 2, p. 69.

von Grotthuss, M., Wyrwicz, L.S., and Rychlewski, L., mRNA cap-1 methyltransferase in the SARS genome, Cell, 2003, vol. 113, pp. 701-702.

Voysey, M., Costa Clemens, S.A., Madhi, S.A., et al., Single-dose administration and the influence of the timing of the booster dose on immunogenicity and efficacy of ChAdOx1 nCoV-19 (AZD1222) vaccine: a pooled analysis of four randomised trials, Lancet, 2021, vol. 397 , no. 10277 , pp. $881-891$.

Walls, A.C., Park, Y.J., Tortorici, M.A., Wall, A., McGuire, A.T., and Veesler, D., Structure, function, and antigenicity of the SARS-CoV-2 spike glycoprotein, Cell, 2020, vol. 181, no. 2, pp. 281-292. https://doi.org/10.1016/j.cell.2020.02.058

Wang, M., Cao, R., Zhang, L., Yang, X., Liu, J., Xu, M., et al., Remdesivir and chloroquine effectively inhibit the recently emerged novel coronavirus $(2019-\mathrm{nCoV})$ in vitro, Cell Res., 2020, vol. 30, pp. 269-271.

WHO, Coronavirus disease 2019 (COVID-19) situation report as of November 30, 2020. https://covid19.who.int/. Accessed November 30, 2020.

Wu, F., Zhao, S., Yu, B., Chen, Y.M., Wang, W., Song, Z.G., et al., A new coronavirus associated with human respiratory disease in China, Nature, 2020, vol. 579, pp. 265-269.

Xia, S., Liu, Q., Wang, Q., Sun, Z., Su, S., Du, L., et al., Middle East respiratory syndrome coronavirus (MERS-CoV) entry inhibitors targeting spike protein, Virus Res., 2014, vol. 194, pp. 200-210.
Xie, H., Efficacy of dipyridamole in the treatment of 116 children with acute upper respiratory tract infections, Chin. J. Sch. Doct., 2010, vol. 24, p. 921.

Xie, M. and Chen, Q., Insight into 2019 novel coronavirus-an updated interim review and lessons from SARS-CoV and MERS-CoV, Int. J. Infect. Dis., 2020, vol. 94, pp. 119-124.

Xie, X., Zou, J., Fontes-Garfias, C.R., Xia, H., Swanson, K.A., Cutler, M., et al., Neutralization of N501Y mutant SARS-CoV-2 by BNT162b2 vaccine-elicited sera, bioRxiv, 2021.

Xu, J., Zhao, S., Teng, T., Abdalla, A.E., Zhu, W., Xie, L., et al., Systematic comparison of two animal-to-human transmitted human coronaviruses: SARS-CoV-2 and SARS-CoV, Viruses, 2020, vol. 12, p. E244.

Xu, Z., Shi, L., Wang, Y., Zhang, J., Huang, L., Zhang, C., et al., Pathological findings of COVID-19 associated with acute respiratory distress syndrome, Lancet Respir. Med., 2020a, vol. 8, pp. 420-422.

Xu, Z., Shi, L., Wang, Y., Zhang, J., Huang, L., Zhang, C., et al., Pathological findings of COVID-19 associated with acute respiratory distress syndrome, Lancet Respir. Med., 2020b, vol. 8, pp. 420-422.

Yang, Y., Peng, F., Wang, R., Guan, K., Jiang, T., Xu, G., et al., The deadly coronaviruses: the 2003 SARS pandemic and the 2020 novel coronavirus epidemic in China, J. Autoimmun., 2020, vol. 109, art. ID 102434.

Yi, Y., Lagniton, P.N.P., Ye, S., Li, E., and Xu, R.H., COVID-19: what has been 794 learned and to be learned about the novel coronavirus disease, Int. J. Biol. Sci., 2020, vol. 16, pp. 1753-1766.

Yoo, J.H., The fight against the 2019-nCoV outbreak: an arduous march has just begun, J. Korean Med. Sci., 2020, vol. 35 , p. e56.

Zhang, J., Xie, B., and Hashimoto, K., Current status of potential therapeutic candidates for the COVID-19 crisis, Brain Behav. Immun., 2020, vol. 87, pp. 59-73.

Zhou, P., Fan, H., Lan, T., Yang, X.L., Shi, W.F., Zhang, W., et al., Fatal swine acute diarrhea syndrome caused by an HKU2-related coronavirus of bat origin, Nature, 2018, vol. 556, pp. 255-258.

Zhu, F.C., Guan, X.H., Li, Y.H., Huang, J.Y., Jiang, T., Hou, L.H., et al., Immunogenicity and safety of a recombinant adenovirus type-5-vectored COVID-19 vaccine in healthy adults aged 18 years or older: a randomized, double-blind, placebo-controlled, phase 2 trial, Lancet, 2020, vol. 396, no. 10249, pp. 479-488.

Zhu, N., Zhang, D., Wang, W., Li, X., Yang, B., Song, J., et al., A novel coronavirus from patients with pneumonia in China, 2019, N. Engl. J. Med., 2020, vol. 382, pp. 727-733.

Zu, Z.Y., Jiang, M.D., Xu, P.P., Chen, W., Ni, Q.Q., Lu, G.M., and Zhang, L.J., Coronavirus disease 2019 (COVID-19): a perspective from China, Radiology, 2020, vol. 296, no. 2, art. ID 200490. 